\title{
A Model CNS Fungal Infection: Cryptococcal Meningitis
}

\author{
Justin Beardsley ${ }^{1} \cdot$ Lam Tuan Thanh ${ }^{2} \cdot$ Jeremy Day $^{2}$
}

Published online: 11 April 2015

(C) The Author(s) 2015. This article is published with open access at Springerlink.com

\begin{abstract}
Cryptococcus spp. are considered 'model yeasts', and the reasons for that are the topic of this review. Several perspectives will be discussed, starting with their characterization and emergence as human pathogens before moving onto their adaptations and the scientific response. The section on characterization illustrates the progress of knowledge and technology over the 120 years since Cryptococcus was first identified, whilst the section on emergence sees this applied to describe the expansion of the host population and environmental niche. The ongoing outbreak in the Pacific northwest of North America is discussed, including some of its drivers. The section on adaptation highlights some insights into how eukaryotes adapt both to their environment and within hosts, and the final section covers the scientific response to this threat in terms of treatment and prevention. The review highlights both clinical and laboratory features of particular interest and places them into the wider context of this still emerging threat.
\end{abstract}

Keywords Cryptococcus $\cdot$ Emergence $\cdot$ Characterization . Adaptation $\cdot$ Environmental niche $\cdot$ Research

This article is part of the Topical Collection on Mycology

Justin Beardsley

jBeardsley@oucru.org

Jeremy Day

jday@oucru.org

1 CNS and HIV Infections Research Group, Oxford University Clinical Research Unit, 764 Vo Van Kiet Street, Ward 1, District 5, Ho Chi Minh City, Vietnam

2 Welcome Trust Major Overseas Programme Vietnam, Oxford University Clinical Research Unit, 764 Vo Van Kiet Street, Ward 1, District 5, Ho Chi Minh City, Vietnam
Cryptococcus spp. are considered 'model yeasts' by many researchers - the reasons for that are the topic of this review. Several perspectives will be discussed, starting with their characterization and emergence as human pathogens before moving onto their adaptations and the scientific response. The section on characterization illustrates the progress of knowledge and technology over the 120 years since Cryptococcus was first identified, whilst the section on emergence sees this applied to describe the expansion of the host population and environmental niche. The ongoing outbreak in the Pacific northwest of North America is discussed, including some of its drivers. The section on adaptation highlights some insights into how eukaryotes adapt both to their environment and within hosts, and the final section covers the scientific response to this threat in terms of treatment and prevention. It is beyond the scope of the review to cover every aspect of cryptococcosis, and the intention is just to summarize current knowledge of key topics and provide a starting point for further reading about this fascinating, complicated and important human pathogen.

\section{A Model for Characterization}

There are 70 species within the genus Cryptococcus. Two of these, Cryptococcus neoformans and Cryptococcus gattii, account for almost all cases of human disease and are amongst the most significant pathogenic yeasts in man, responsible for a large burden of mortality and morbidity [1-3]. They are widely dispersed throughout the environment; $C$. neoformans is associated with avian guano [4], and C. gattii's first identified environmental niche was the Australian Red River gum tree $[5,6]$ - although both species have subsequently been isolated from a wide variety of trees [7-9]. Their global distribution and ability to cause disease are driven by the species 
or varietal form; the vast majority of cases occur in immunocompromised hosts, although disease in the immunocompetent is increasingly recognized [4, 10-12]. However, in general Cryptococcus spp. are not considered to be primary human pathogens; rather, the ability to cause disease is an accidental result of some adaptation to their usual saprophytic niche.

\section{Speciation}

Cryptococcus neoformans was first identified in 1894 following isolation from peach juice $[13,14]$ and almost contemporaneously identified as a pathogen in a patient with osteomyelitis [15]. Unlike other Saccharomyces spp., the organisms identified by Sanfelice and Busse did not ferment carbon sources nor form ascospores - and for this reason in 1901, they were transferred to the genus Cryptococcus [10]. The Cryptococcus genus consists of basideomycetous saprophytes, remarkable for their polysaccharide capsule, which varies in size depending upon the environment in which the yeast finds itself. The capsule is a key determinant of virulence, and it is postulated that it enables survival of the yeast within free-living amoebae or other simple organisms. The capsule is easily identified on India Ink staining of clinical specimens; characteristic budding is often seen.

Pathogenic Cryptococci can be distinguished serologically. In 1935, Benham described serotypes A, B and C, using sera raised from inoculated rabbits [16]. The resolution of this method was improved by Evans in the 1950s [17, 18] enabling the identification of serotype D in the late 1960s and a hybrid form (AD) in the 1980s [19, 20]. Cryptoccoccus neoformans var. grubii generally types as A, Cryptoccoccus neoformans var. neoformans generally as D and Cryptococcus gattii types as $\mathrm{B}$ or $\mathrm{C}$-but there are exceptions which make serological typing alone inadequate for accurate speciation [21].

\section{Genotyping}

Molecular typing techniques, notably restriction fragment length polymorphism analysis [22], amplified fragment length polymorphism analysis [23] and multi-locus sequence typing [24] have generally supported and clarified the pre-existing classification systems. However, they have also been instrumental in identifying new species, removing incorrect interspecies distinctions and informing the decision to raise Cryptococcus neoformans var. gattii from a varietal form to a species in its own right $[10,25,26 \bullet]$. Earlier observations that isolates were antigenically dissimilar, had different ecological niches and caused a different spectrum of disease (see below) have been validated by sequence-based technologies demonstrating that the two forms are evolutionarily distinct $[27,28]$, having diverged 40-80 million years ago [29, 30]. This progress demonstrates how advances in the technologies used for classification have deepened the understanding of the genus and how this genus can be used as a model for progressive, systematic classification.

The polymerase chain reaction restriction fragment length polymorphism (PCR-RFLP) analysis of the URA5 gene has been particularly useful [22]. This simple tool divides C. neoformans into five genotypes (VNI-VNIV and VNB) and C. gattii into four (VGI-VGIV). The genotypes provide a basis from which to understand phenotypes, correlating with features such as outbreak epidemiology [10], antifungal susceptibility and virulence [31, 32]. However, recently, it has been noted that these genotypes have variable degrees of genetic heterogeneity, and some may benefit from subdivision (e.g. VGII being divided into $\mathrm{a}, \mathrm{b}$ and $\mathrm{c}$ in the Vancouver Island outbreak - see below). Some genotypes may be sufficiently distinct to be classified as varieties, or even 'cryptic species'-VG genotypes demonstrate distinctiveness at least equivalent to that seen between $C$. neoformans vars. grubii and neoformans [26•, 33, 34•]. Taxonomical debates continue as classification systems keep pace with developing technology $[25,35]$.

\section{Metabolic Phenotype}

Biochemical profiling can identify and distinguish Cryptococcus species, with the most obvious example being the use of Canavanine-Glycine-Bromothymol Blue (CGB) Agar to distinguish C. neoformans from C. gattii-because C. gattii is resistant to canavanine and can utilize glycine, its successful growth effects a change in $\mathrm{pH}$ which turns the medium blue, a pattern not seen with $C$. neoformans [36]. Other simple tests used for clinical identification include production of urease and melanin [4]. Commercial identification systems, such as API 20C AUX ${ }^{\mathrm{TM}}$ (bioMérieux SA, Marcyl'Etoile, France) and Vitek ${ }^{\mathrm{TM}}$ (bioMérieux Inc., Hazelwood, USA) systems take advantage of species-specific carbohydrate utilization allowing cheap and rapid identification based on biochemical profiling [37].

Proteome analysis promises to offer increased insights into understanding the pathogenicity of complex organisms such as Cryptococcus sp., where post-translational modification may account for differences between strains [10, 38, 39]. Matrix-assisted laser desorption/ionization time of flight technology (MALDI-TOF) has made accurate quantification of protein components readily available to research and clinical laboratories. MALDI-TOF is cheap to perform, rapid and capable of high throughput [40]. Beyond use as a diagnostic tool, such analyses can demonstrate how virulence factor expression is affected by exposure to stressors such as temperature, radiation or chemicals [38, 41-43, 44•]. An example is how nitric oxide exposure results in upregulation of the antioxidant agents thioredoxin and glutathione and oxidoreductases involved in the yeast stress response and also results in 
post-translational protein modification [42]. Mass spectral technologies have also been applied to biofilms, which play a role in cryptococcal virulence and have demonstrated that biofilm organisms upregulate proteins associated with defence (e.g. antioxidant, proteolytic or stress response proteins) whilst downregulating proteins associated with development (e.g. those responsible for translation, transcription and microtubule formation) [44•]. Key outputs hoped for from these new approaches are explaining mechanisms of drug resistance, identifying markers of resistance and identifying new drug targets $[39,45]$.

\section{A Model for Emergence}

Since its discovery, Cryptococcus has transformed from a rare pathogen to one estimated to infect one million and kill over 600,000 individuals each year [1]. There are no accurate estimates for the global incidence of non-HIV-associated cryptococcosis: sporadic cases in apparently immune-competent hosts persist [2, 46-50], but in addition, large outbreaks in immune-competent populations have recently been described and are discussed below. The common driving factor behind these areas of growth is exploitation of new niches, and the most dramatic example of this is the HIV pandemic, which continues to be the commonest risk factor globally. However, in rich countries, ongoing emergence is increasingly driven by non-communicable causes of immune deficiency [2, 46, 47, 50-52] including iatrogenic immunosuppression due to solidorgan transplants or biological immunomodulatory therapies [52-54].

\section{Emergence of Cryptococcus neoformans as an Endemic Pathogen}

Recent developments in the understanding of the origin of the $\mathrm{AD}$ hybrid serotype have led to the postulation that the evolutionary source of C. neoformans is Africa. Cryptococcus sp. has two mating types, $\alpha$ and a, and can exist in haploid or diploid forms. In its haploid form, it demonstrates a single mating-type allele (' $\alpha$ ' (MAT $\alpha$ ) or 'a' (MATa) with the diploid forms expressing one or both alleles (aa, $\alpha \alpha, a \alpha)$. Only haploid cells mate, typically attracting their opposite mating type with the secretion of pheromones, developing projections and fusing to produce diploid progeny, which then quickly divide by meiosis into four new haploid organisms, with varying degrees of recombination [4]. For convenience, these forms are annotated as follows: for haploids, serotype $\mathrm{X}$, mating-type y $(X y)$; for diploids $y X X y$. So, serotype A with the MAT $\alpha$ mating-type allele (the commonest combination globally [4]) would be $\mathrm{A} \alpha$; serotype $\mathrm{AD}$, with A carrying the MATa mating-type allele and D the MAT $\alpha$, would be $\mathrm{aAD} \alpha$.
Interest in the origins of the $\mathrm{AD}$ hybrid resulted from the anomalous fact that almost all global isolates of serotype A demonstrate the $\operatorname{MAT} \alpha(\mathrm{A} \alpha)$ mating-type allele [4], yet serotype $\mathrm{AD}$, which is also globally distributed, frequently demonstrates the serotype A MATa mating-type allele $(\mathrm{aAD} \alpha)$ [55]. Various explanations were proffered, including the idea that Aa became extinct overtime and that the aAD $\alpha$ hybrid predated this extinction. Another suggestion was that Aa had an unidentified environmental niche or lacked virulence and so was seldom isolated due to sampling bias.

However, the discovery of a genetically distinctive serotype A (VNB genotype) subpopulation in Botswana raised new and intriguing possibilities [24, 55]. The proportion of $C$. neoformans var. grubii with the MATa allele in Botswana is around $25 \%$, compared with a global proportion of less than $0.1 \%$, and the population structure shows a high degree of heterogeneity not seen in other geographic regions [24]. In 2007, Litvintseva and colleagues used a combination of AFLP- and MLST-based phylogenetic analyses to show that the Botswanan Aa was very closely related to the Aa genes in global aAD $\alpha$ hybrids from China, Europe and the USA [55]. They then considered the impact of hybridization on fitness, using UV irradiation as a stressful event and comparing the response of Botswanan $\mathrm{Aa}$ and $\mathrm{A} \alpha$ isolates, with reference $\mathrm{A} \alpha$ isolates, lab-generated aAD $\alpha$ hybrids, wild-type $\mathrm{aAD} \alpha$ hybrids and reference serotype $\mathrm{D}$ isolates. Botswanan Aa isolates were more sensitive to UV radiation than any other isolate, and hybridization with $\mathrm{D}$ conferred significant UV resistance [55]. These two pieces of information form the basis of the hypothesis that a large proportion of the global AD population resulted from a hybridization event in Botswana, producing a fitter organism, which was able to go on and colonize the world.

Colonization may have been facilitated by a combination of the great human migrations, expansion of domesticated pigeon populations and the huge expansion of international trade in Africa driven by European imperialism [55-60]. This theory has been further supported by research in Thailand, where a genetic bottle neck, analogous to a founder effect, was identified in C. neoformans var. grubii isolates [57]. Strong signatures of clonality were detected, with the null hypothesis of random recombinations being rejected, in stark contrast to the genetic heterogeneity seen in African isolates [57]. The mean time to the most recent common ancestor was estimated to be approximately 7000 years ago, well after the currently estimated dates for the human out-of-Africa migration [58, 61, 62], suggesting Cryptococcus left Africa with man, pigeons and perhaps other vectors to ultimately expand clonally in new geographic locations. This ex-African clonality has been described in multiple other geographic locations, and is believed to demonstrate an epidemic population structure for the organism [12, 24, 63, 64]. 


\section{Emergence of Cryptococcus gattii as an Agent of Outbreaks}

Cryptococcus gattii is estimated to have diverged from C. neoformans approximately 40 to 80 million years ago $[29,65]$. It was first described in 1970 in a Congolese patient with cryptococcosis; the infecting isolate was found to have a distinctively different morphology. Instead of the usual uniform round or oval forms seen with C. neoformans, this new isolate produced frequent elongated or bacilliform morphotypes [66, 67]. Subsequently, a number of human cases were described in Australia, and pioneering work was undertaken to identify its environmental niche [6, 68]. Following extensive sampling of plants, their debris, soil and air, the major niche was identified as the Red River Gum, Eucalyptus camaldulensis. Since then, numerous other tree species have been identified as habitats; the particular niche appears to be rotting bark and wood, as well as soil beneath the canopy $[8,9$, 34-, 69-73]. Historically, the incidence rates of $C$. gattii cryptococcosis have been highest in Papua New Guinea (42.8/ million/year) and Australia's Northern Territory (8.5/million population/year) [74]. Unlike disease due to C. neoformans, patients diagnosed with $C$. gattii usually have no identified immune deficiency, and pulmonary involvement is more common $[75,76]$. Host factors may have an impact on the risk of disease - in Australia, the incidence rate in the aboriginal population is $10.4 /$ million/year compared to the non-indigenous population rate of $0.7 / \mathrm{million} / \mathrm{year}$, and the difference is not thought to be wholly explained by differences in geography [74].

It was previously believed that $C$. gattii was limited to the tropics and subtropics, but it is increasingly being recognized in temperate regions. The ongoing outbreak on Canada's Vancouver Island and in the Pacific northwest of the USA provides an excellent illustration of a pathogen exploiting a new environmental niche; incidence there is now $25.1 /$ million/year [77].

The various $C$. gattii genotypes differ in their global distribution, reproductive behaviour and pathogenicity. The VGII genotype appears to be the oldest, estimated to have diverged from a common ancestor 12.5 million years ago; VGIV diverged 11.7 million years ago; and VGI and VGIII diverged from each other 8.5 million years ago [29]. VGI is the genotype most prevalent in Australasia and Europe, VGII is most prevalent in South and North America (including the current Pacific North West outbreak), VGIII is more common in North and South America than other regions (but not predominant), and VGIV is the most frequently described in Africa $[26 \bullet, 78]$. The genotypic spread of $C$. gattii and $C$. neoformans is depicted in Fig. 1. The data (review by Cogliati, 2013) contains a combination of human, veterinary and environmental samples from 2012 and earlier which were not necessarily collected under formal surveillance nor randomized sampling programmes. Despite these limitations, it is interesting to note the regional variations, especially in C. gattii [79].

\section{Vancouver Island Outbreak}

Since 1999, there has been an outbreak of $C$. gattii disease centred around Vancouver Island, Canada, and by 2009, it had spread to northwestern USA [80]. This outbreak has largely resulted from clonal expansions of three subtypes of VGII (VGIIa, VGIIb and VGIIc). VGIIa dominates, and is termed the 'major' strain. Laboratory models suggest it has enhanced virulence - it replicates rapidly within macrophages, with a high intracellular proliferation rate (IPR), and leads to shorter survival times in the mouse infection model. Interestingly, this increased virulence may in part be explained through mutations in its mitochondrial genome $[32,81 \bullet]$. Voelz et al. recently clarified the previously described link between VGIIa's increased IPR and its capacity to transform its mitochondrial morphotype to tubular (from globular) [81•]. It had already been noted that a tubular mitochondrial morphotype was commoner in the pathogenic outbreak strain [32]. Using timelapse images, it was noted that VGIIa cells can rapidly tubularize their mitochondria in response to oxidative stress, becoming significantly less likely to be killed by the macrophage and yet slower to replicate than those with globular mitochondria. The finding of reduced fecundity, in a strain with a higher IPR, was explained by the observation that the remaining yeast cells (with globular mitochondria) replicated very rapidly. In the presence of the resistant but nonreplicative VGIIa tubular mitochondrial morphotype, even non-outbreak strains are stimulated to increased IPRs, suggesting a signalling pathway whereby yeast cells establish a 'division of labour' [81•]. This may have implications for other infections and especially co-infections occurring in the presence of $C$.gattii [81•].

VGIIb, which is termed the 'minor' strain, demonstrates less virulence than VGIIa in both in vitro and in vivo models $[32,82]$, although a difference in human outcomes has been harder to demonstrate [77]. VGIIb is responsible for less than $10 \%$ of cases in this outbreak, and because many of those affected are in older age groups, it is difficult to compare clinical outcomes [77]. VGIIc is similar to VGIIa genotypically and phenotypically but is unique to the USA. It was first isolated in Oregon and appears to be the result of a recombination event, either locally or prior to import [32]. Currently in Oregon, VGIIc causes $27 \%$ of infections and VGIIa approximately $63 \%$ [83•], compared to 0 and $86.3 \%$, respectively, in British Columbia [77].

The origin of the outbreak strains has been the source of debate. Until recently, evidence was balanced between the likeliest candidates: South America, Africa and Australia (which all had evidence of recombination and genetic diversity). However, recently, the case for South America has 
Fig. 1 Paired pie charts representing the genotypic distribution of $C$. neoformans (left) and C. gattii (right) in North America, South America, Europe, Africa, Asia and Oceania. The size of each chart represents the number of genotyped isolates in the analysis for that region, out of a global total of 8077. Data from Cogliati 2013 [79]

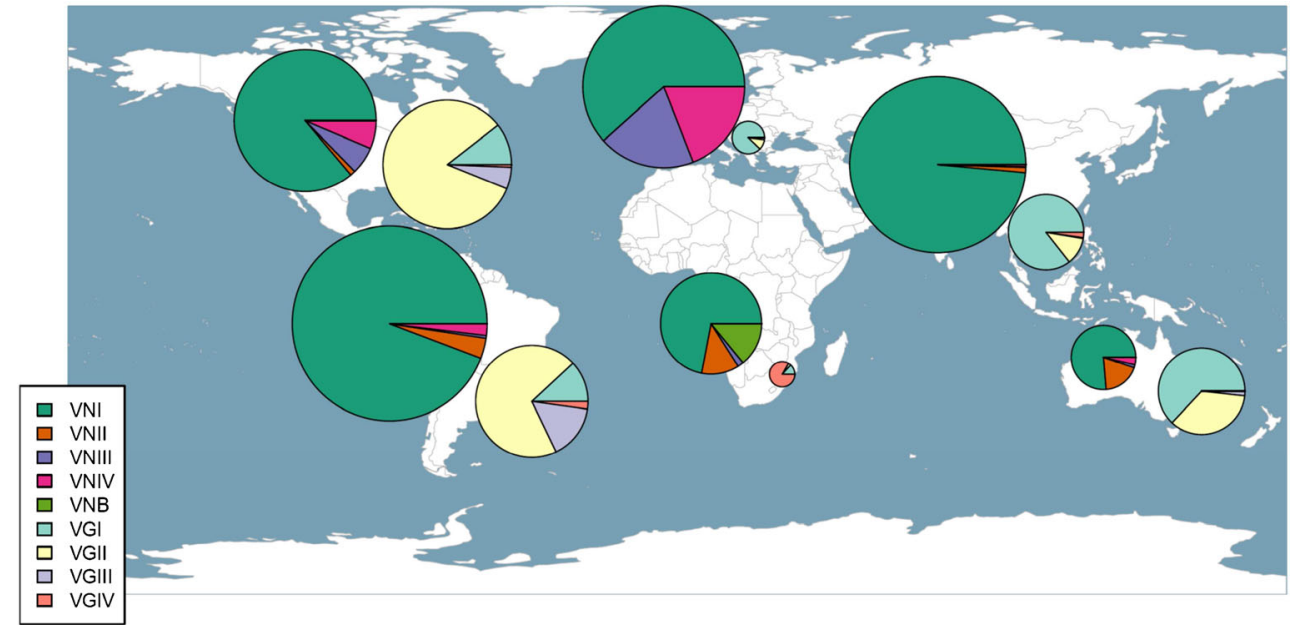

strengthened [29], due to the discovery of a strain displaying a basal genetic lineage in virgin Amazonian rainforest, where contamination from imported woods is thought extremely unlikely [84].

Ultimately, it is hoped that better understanding the relationships between subtypes and the environmental niche will enable the public health community to predict the likely range of current outbreaks and regions at risk of outbreaks in the future [85].

\section{A Model for Adaptability}

\section{Virulence in Animal Hosts Results from Adaptation for Survival in the Environment}

Cryptococcus spp. are primarily environmental saprophytes. Human-to-human transmission does not occur, and therefore adaptive pressures that confer pathogenicity must come from the non-human environment. It is widely held that the ability to cause disease is due to the coincident pathogenic potential of adaptations to its local environment: so-called 'bystander pathogenicity' $[86,87]$. C. neoformans possesses a variety of specialized virulence factors, including an external polysaccharide capsule, the ability to grow at mammalian body temperature, production of laccase and melanin, and a number of secreted factors (including phospholipase B and urease [88]) important for surviving the host immune response [10]. Although Cryptococcus spp. can infect hosts ranging from amoebae to mammals, there is no evidence that a susceptible host is required at any stage of the life cycle. Even pigeons, considered to have an important role in the global dispersal of C. neoformans, are not susceptible to cryptococcosis so are unlikely to exert evolutionary pressure $[4,89]$. So, given the myriad interactions between $C$. neoformans and other environmental organisms, current data suggest that selection pressures from environmental stress and predation have led to the acquisition of a unique set of cryptococcal attributes, which just happen to be useful in mammalian infection, rather than there being some obligatory stage within a (as yet unidentified) mammalian host. Some of these attributes are described below.

\section{Uptake and Subsequent Intracellular Proliferation}

Ruiz et al. (1982) observed that $99.9 \%$ of C. neoformans could be ingested and killed by Acanthamoeba palestinesis trophozoites after 7 days and that it could also be ingested by mites and sowbugs - all found in pigeon guano [90]. Ingestion of $C$. neoformans by $A$. castellani is followed by intracellular replication and the accumulation of cytosolic vesicles containing shed capsular polysaccharide [91]. Replication is impaired in mutants with deficient capsules or phospholipase, and acapsular mutants are more readily killed after ingestion $[92,93]$. Melanin production may also protect against amoeba predation since, even in acapsular strains, melanized individuals are more likely to survive ingestion $[92,93]$. Thus, factors associated with virulence in mammals may have evolved to fulfil a role in cryptococcal interactions with amoeba.

The interactions of $C$. neoformans with amoeba and host macrophages are strikingly similar. In mammals, C. neoformans is a facultative intracellular pathogen which can survive phagocytosis by innate immune cells and proliferate intracellularly [10]. The development of such transferable intracellular survival skills may help to explain the broad host range of $C$. neoformans: all major mammalian immune responses rely on phagocytic effector cells. Following invasion of the phagocyte by Cryptococcus, there may be dissemination by non-lytic extrusion of yeast cells to both the extracellular space and adjacent host cells ('vomocytosis') [92, 94-99]. This potential 'Trojan horse' effect may be the key in establishing central nervous system infection [100-102]. Cryptococcus' complex pattern of interaction with host innate 
immune cells is a key determinant of virulence-both intracellular proliferation rate (IPR) and phagocytosis proclivity have been correlated with mortality for $C$. gattii, and an enhanced ability to survive and replicate inside macrophages has been shown to be associated with its spread in northwestern North America and may even have triggered the outbreak [98, 101, 103-105].

For C. neoformans, in contrast to C. gattii, it seems initial yeast uptake by macrophages, rather than IPR, correlates with cerebrospinal fluid (CSF) fungal burden [103]. Infection with high-laccase activity, high-uptake $C$. neoformans correlates with higher pre-treatment fungal burden in patients' CSF and slower rates of fungal clearance with treatment [103]. In this case, strains with smaller capsules are more readily engulfed by macrophages and have enhanced intracellular survival.

\section{Capsule}

C. neoformans' capsule is unique amongst human pathogenic yeasts and is comprised of polysaccharides (glucuronoxylomannan (GXM) and galactoxylomannan $(\mathrm{GalXM})$ ) and a lesser proportion of mannoproteins (MP)) [106]. In addition to the effects on phagocytosis by amoebae described above, the capsule may also protect against dehydration and dessication in low humidity conditions [107].

The role of the capsule in pathogenesis and defence against the mammalian immune response is well established [106, 108, 109]. Acapsular C. neoformans strains have reduced pathogenicity in mice; the capsule promotes survival in their lungs, dissemination to the brain and induces a more subdued cellular response $[110,111]$. The capsule also protects unopsonized yeasts from ingestion by phagocytes in vitro, depletes complement components and impedes immune response [112]. Capsular polysaccharide materials induce proliferation and differentiation of normal CD4+ T cells into Th2 phenotype, favouring intracellular parasitism and dissemination [113]. The fact that acapsular C. neoformans strains are only capable of causing prolonged brain infections in nude mice (absent or deficient thymus) demonstrates the key role of capsule in virulence [4]. Despite this, links between capsule size and virulence were not demonstrated until recently when a paper by Robertson et al. showed a larger ex vivo capsule size was associated with higher opening CSF pressure and a paucity of CSF inflammation [109]. They also showed that the larger capsule size was associated with more shedding of capsular antigens and viscosity of the CSF, which may be a mechanism for the elevated CSF pressure [109].

\section{Growth at $37^{\circ} \mathrm{C}$}

The ability to grow at mammalian body temperatures $\left(37^{\circ} \mathrm{C}\right.$ or higher) is an obvious yet essential attribute for any wouldbe invasive fungal human pathogen [114-117]. There are several explanations for the origin and evolution of thermotolerance in $C$. neoformans. It has been hypothesized that a bolide collision 65 million years ago eliminated a vast proportion of the Earth's fauna and triggered a global chain reaction of volcanic and seismic activities, giving rise to a massive fungal bloom that fed on decaying vegetation [114]. Under these conditions, endothermy was a costly but effective adaptation for surviving mammals and birds species to offer protection against such a large fungal inoculum. Fungi would have to adapt too to successfully infect, colonize and cause disease in these new endothermic hosts [114] _however, this adaptation would not be critical for an organism that does not require mammalian hosts, so adaptations to warmer environments may offer a likelier explanation.

Strains of $C$. neoformans have been shown to be able to grow in a temperature range of 30 to $40{ }^{\circ} \mathrm{C}$ [117], but there is a considerable variation in thermotolerance between different C. neoformans strains, and some evidence that this is determined by geographic origin. For instance, C. neoformans var. neoformans strains, which in general are more susceptible to high temperature than their globally distributed $C$. neoformans var grubii siblings, are more prevalent in temperate regions of Europe [118]. Evidence that Cryptococcus spp. originated in sub-Saharan Africa further supports the speculation that growth at higher temperatures, essential for pathogenicity, is a survival advantage that resulted from environmental selection pressures in regions with higher ambient temperatures [7, 119].

\section{Laccase and Melanin Production}

Melanin is a brownish black pigment produced through oxidative polymerization of phenolic compounds. C. neoformans produces melanin with an oxidative enzyme called laccase which synthesizes melanin from L-DOPA, dopamine, norepinephrine and epinephrine [120-122]. Environmental isolates of C. neoformans are often melanized; melanization may have evolved as a survival strategy to protect cells from UV radiation and facilitate growth at extreme temperatures [123-125]. Defects in melanin production result in improved mouse survival in infection models [122] and have been shown to protect against enzymatic degradation, antimicrobial peptides, oxidative stress and heavy metal toxicity [126, 27-129]. Of note, it also decreases the efficacy of amphotericin B in vitro [128]. Moreover, clinical isolates with higher laccase activity have higher ex vivo CSF survival and are more resistant to antifungal treatment [103].

\section{Cryptococcus also Displays In-Host Adaptations}

\section{Morphology Switching}

Cryptococcus spp. are capable of morphological transformations, and these can occur during infection. Such 
transformations include filament formation during mating, and upregulation of capsule synthesis to produce giant cells averaging $40-50 \mu \mathrm{m}$ in diameter $[93,106,130,131]$ (see Fig. 2), but up to $100 \mu \mathrm{m}$ [132]. In mouse models, the giant cell subpopulation can vary between 10 and $80 \%$ of the total pulmonary fungal population, depending on the duration of infection, degree of inflammation and total fungal burden [93]. Mice infected with a lower dose of yeasts, with less inflammation, produce a higher proportion of giant cells [93]. These giant cells are often polyploid but uni-nucleated, suggesting DNA replication without subsequent completion of mitosis and/or cytokinesis. This variable chromosomal ploidy in the giant cell population indicates both dynamic flexibility and stability of the cryptococcal genome $[88,93$, 132].

Pheromone and cyclic AMP-dependent signalling pathways have been shown to be major regulators of cryptococcal cell gigantism [88, 93, 133-135]. Temperature has been identified as a stimulus for this change in some strains [136]. The formation of giant cells may be a survival strategy facilitating evasion of host immune defences: giant cells are frequently found in extracellular spaces and are more resistant to phagocytosis than regular yeast cells, perhaps representing an extracellular subpopulation, co-colonizing with an intracellular population of smaller cells which have utilized phagocytosis to facilitate dissemination. Lower CSF fungal burdens in patients with chronic or latent (extra-CNS) infections are in keeping with the observation that lower inocula seem to induce more gigantism [88], leaving fewer regular cells to hijack macrophages to gain access to the CSF. Morphological heterogeneity presents an obstacle for the immune response, which may explain some of the observed difficulties in cryptococcal disease therapy [129].

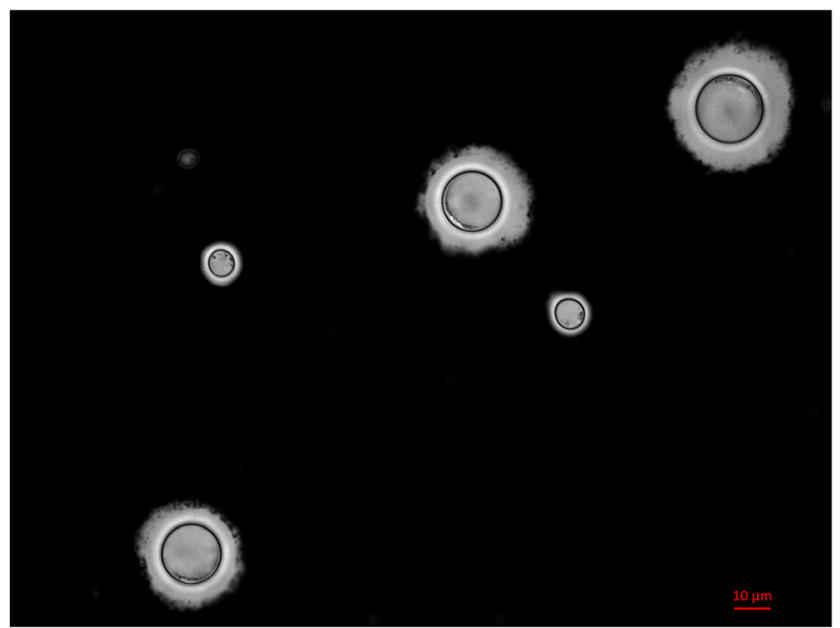

Fig. 2 India ink staining of a Vietnamese clinical isolates of Cryptococcus neoformans var. grubii showing giant cells alongside standard-sized counterparts. Image courtesy of Lam Tuan Thanh, OUCRU, Vietnam

\section{Genome 'Flexible Stability' and Survival-Driven Adaptability}

Early characterization of cryptococcal genomes came from electrophoretic karyotyping [137]. Both the size and number of chromosomes were highly variable in clinical and environmental isolates, suggesting extensive chromosomal rearrangement and genomic flexibity [138]. Further investigation revealed the extent of variation within the population and suggested meiotic-driven karyotypic variation $[139,140]$. Karyotype changes also occur within a single infection; this was observed in a series of human cases and confirmed in the mouse model [141]. Gross chromosomal rearrangement has been observed in closely related strains isolated from the same patient 77 days apart, further supporting host-selective pressures as a driving force behind this genome flexibility [142-144].

Full genome sequences became available for C. neoformans var. grubii in 2001 and C. neoformans var. neoformans in 2005. Despite karyotypic variability, these closely related varieties share over $80 \%$ sequence homology and are largely collinear [145] though not at the subtelomeric regions, centromere or MAT loci [146]. The retention of such similarity is remarkable given their separation over millions of years, and the combination of genomic stability with the capacity to undergo extensive chromosomal rearrangement upon selective pressure is something of a paradox [142].

This genomic flexibility is likely a response to within-host pressures and could be considered a virulence-associated phenotype with possible consequences for treatment. For example, the capacity for aneuploidy may be a key factor in conferring resistance to fluconazole [147-149]. This phenomenon is seen in Candida albicans, where chromosomal rearrangement and duplication is proposed as a mechanism allowing populations to respond to selective pressures [150]. This has been termed heteroresistance, whereby a subpopulation of resistant organisms exists amongst a larger population of susceptible siblings, thanks to some degree of genomic plasticity. Various studies on azole heteroresistance in $C$. neoformans have demonstrated disomy in chromosomes 1 and 4 occurring in resistant subpopulations selected from growth conditions containing high antifungal drug levels [147, 151]. Resistant clones emerging in media with the highest drug levels were found to have disomies in four chromosomes: Chr1, 4, 10 and 14 [147, 151]. Amplification of ATP transporter efflux pump genes like Ergll and Afrl on Chrl was shown to correlate with azole resistance [147], and disomy on Chr4 has been associated with genes required for endoplasmic reticulum integrity under azole stress [151] — there may be other mechanisms to be discovered. 


\section{A Model for Scientific Response}

Medical research into the appropriate management of cryptococcal disease has increased rapidly since the advent of the HIV epidemic [1]. Unlike many CNS infections, cryptococcal meningitis is relatively easily diagnosed, with high fungal burdens and a distinctive pathogen that can be seen with a number of non-specific staining and culture methods or identified with highly sensitive antigen detection kits [4]. However, outcomes remain unacceptably poor-with a 90 -day case fatality rate of up to $70 \%[1,3,77,152 \cdot]$. Even when best available treatments are provided in well-resourced settings, mortality is upwards of $10-15 \%[3,77]$.

\section{Antifungal Therapy—a Model for Clinical Research}

Amphotericin B was the first treatment available for cryptococcosis and became available in the late 1950s [4]. The arrival of fluconazole in the 1980s, with its excellent oral bioavailability and tolerability, revolutionized treatment enabling the shortening of duration of amphotericin treatment and the long-term suppressive therapy required by immune suppressed patients. There have been almost 40 randomized controlled trials of antifungal therapy in cryptococcal disease, although in general, these have been small (the median number of patients randomized is 58), and have not been powered to survival (see Table 1). Rather, trials tended to use composite endpoints consisting of survival, clinical improvement and sterilization of cerebrospinal fluid. A major focus for the first trials was testing increased doses of amphotericin, shortening treatment regimens and combination treatment with flucytosine [153-155].

A landmark paper was the 1997 AIDS Clinical Trials Group and Mycoses Study Group study of 379 participants, comparing treatment with higher dose amphotericin monotherapy to flucytosine combination therapy. This established the amphotericin-flucytosine combination as the gold standard for HIV-infected patients with improved clinical and mycological outcomes; however, the trial lacked power to demonstrate a survival effect [155]. Combination therapy has formed the backbone of treatment recommendations since then [156]. In 2013, the survival benefit was demonstrated in a large trial from a single centre in Vietnam [152•]. Flucytosine also leads to improved outcomes and more rapid fungal clearance when combined with fluconazole (compared to fluconazole monotherapy), although studies have been small [157-159]. Unfortunately, access to both amphotericin, and in particular flucytosine, is extremely poor in the locations where most disease occurs [160]. Direct comparisons of nonamphotericin containing combination treatments with amphotericin-based combination treatments are underway [161].

In settings where flucytosine is not available, the combination of amphotericin with fluconazole is recommended [156], although there is no clear evidence that this improves mortality. Patients receiving 2 weeks of induction treatment with amphotericin combined with fluconazole had similar outcomes at 10 weeks and 6 months to patients receiving 4 weeks of amphotericin monotherapy [152•].

Trials in cryptococcal disease are challenging. HIVinfected patients are complex with multiple health needs and require prolonged follow-up; this in part explains the relative paucity of data to inform treatment decisions. The development of early fungicidal activity (EFA) as a measure of treatment effect offers the chance to speed treatment development. Following its conception in Thailand and its subsequent use in numerous intervention studies, there is hope that it will eventually serve as a robust surrogate marker of the efficacy of antifungal treatments [162-167]. Differences in EFA provide biological plausibility for the differences in survival seen with different treatments in the Vietnamese study [152•].
Table 1 Cryptococcal trial summary statistics as of 1979 2014

\begin{tabular}{ll}
\hline Factor & Value \\
\hline Estimated number of cases of CM per year in HIV patients $^{\mathrm{a}}$ & 957,900 \\
Estimated number of CM deaths per year $^{\mathrm{a}}$ & 624,700 \\
Number of patients with CM randomized in treatment trials $^{\text {Studies powered to mortality }}$ & 3182 \\
Studies that have shown a mortality difference & 1 \\
Number of randomized controlled trials (RCTs) in cryptococcal meningitis & 3 \\
Median number of patients per RCT & 35 \\
Percentage of trials with less than 100 patients & 58 \\
Percentage of trials in HIV patients & 75 \\
Median days from receipt of funding to randomizing first patient in a trial $^{\mathrm{b}}$ & 92 \\
\hline
\end{tabular}

${ }^{\text {a }}$ Estimates from Park et al, AIDS 2009

${ }^{\mathrm{b}}$ Refers to any clinical intervention trial in any disease 


\section{Adjuvant Therapies}

Because of a lack of new antifungal agents, several groups have undertaken research seeking options for adjuvant therapies including corticosteroids [168], IFN- $\gamma[169,170 \bullet]$ and acetazolamide [171]. Results from the corticosteroid trial are yet to be published, IFN- $\gamma$ has been shown to have a statistically significant impact on EFA (but not mortality) and the acetazolamide trial was discontinued early due to an excess of adverse advents, likely due to additive toxicity with amphotericin. Currently, none of these adjuvants can be recommended in routine clinical care.

The timing of initiation of antiretrovirals (ARVs) in HIV co-infection has been a key area of interest over recent years, with a need to balance the benefits of ARVs (especially with regards to opportunistic infections) with the possible harmful consequences of immune reconstitution syndromes. In pulmonary tuberculosis, early initiation appears to be beneficial, although this effect was not seen in a randomized trial in TB meningitis [172-175]. In cryptococcal meningitis, the COAT trial (2014) found that early initiation of ARVs was associated with an increased risk of death and appeared to carry no benefit in terms of reduced incidence of opportunistic infections $[176 \bullet$. Previous smaller studies also suggested probable increased risks of harm with early initiation of ARVs [177, 178]. It is hypothesized that the increase in mortality is related to immune reconstitution inflammatory syndrome (IRIS) and that the impact is greater earlier in the course of treatment, when the patient has not yet begun to recover from the original intracerebral insult and has limited reserves. In keeping with this theory, Boulware et al. noted that the increased mortality was especially pronounced in patients with a baseline CSF white cell count $<5$ cells $/ \mathrm{mm}^{3}$ [176 ], an established risk factor for IRIS [179, 180].

Perhaps the most valuable adjuvant in the treatment of cryptococcal meningitis is the management of raised intracranial pressure. International guidelines recommend that pressure should be maintained below $25 \mathrm{~cm}$ of CSF, with daily lumbar punctures if necessary [181]. Pressure is elevated at presentation in over half of patients [152•,176•, 182], and failure to comply with management guidelines has been associated with adverse outcomes [183] - fears about frequent lumbar punctures leading to harm appear to be unfounded [184, 185]. However, there have not been any prospective trials comparing different pressure management methods.

\section{A Model of Early Detection and Treatment}

Current antifungal and adjuvant options have yet to achieve the large reductions in mortality required in cryptococcal meningitis but perhaps an upstream approach could. Early diagnosis is invariably beneficial in the management of infectious diseases, and there is much interest in the use of lateral flow antigen (LFA) detection test for cryptococcal antigen (CrAg) to diagnose a pre-symptomatic stage of cryptococcal meningitis where treatment efficacy may be improved. Undoubtedly, the LFA test brings opportunities to improve standard diagnostics in resource-limited settings [186], as it requires little equipment, no electrical power and minimal training. CrAg positivity has been shown to predate symptoms of cryptococcal meningitis by several weeks [187] and is associated with increased mortality $[188,189]$. Modelling suggests that systematic screening and treatment could be a costeffective intervention in selected patient populations [190-192], and screening of asymptomatic patients is being introduced in South Africa on a country-wide scale. However, the best treatment for asymptomatic antigenaemia is unknown. A prospective observational cohort suggested a benefit of pre-emptive administration of fluconazole in such patients, but dosing schedules were uncontrolled and varied considerably, preventing the formulation of a treatment recommendation [190]. Further work in this area is urgently needed. Another area of concern is illustrated in a study from Cambodia which showed that many outpatients with antigenaemia, without meningism, had evidence of disease on CSF examination [193]. An acceptable CrAg screening strategy would need to ensure patients with cryptococcal meningitis (CM) continued to receive evidence-based therapy.

A simplified but common format for a screen and treat approach is depicted in Fig. 3 [194•]. Importantly, it acknowledges that optimal treatment for asymptomatic antigenaemia has not been established and that lumbar puncture should be performed whenever feasible to exclude CM [195]. Such a programme was predicted to be cost-effective in a Ugandan study [190], and two studies in South East Asia suggested implementation would cost less than 300 USD per life year gained (depending on actual prevalence of CrAg positivity, and fluconazole drug costs) - even at the top end of this range, the intervention would be classified as 'very cost-effective' under WHO guidelines [191, 192].

However, when implemented in an ambulatory care setting in Kenya, 782 patients were enrolled into the screen and treat intervention and offered high-dose fluconazole followed by a maintenance dose if they tested positive. Unexpectedly, the study failed to demonstrate any overall mortality benefit to the intervention. The study was compromised by poor uptake of the intervention and the fact that historical controls were used, but in this 'real world' setting, there was little to suggest any benefit [196•]. A different approach in Tanzania, where a universal screening of hospitalized HIV patients was undertaken, failed to improve diagnostic accuracy beyond standard of care and did not demonstrate a mortality benefit [197]. In both studies, due to local resource issues, all patients received 
Fig. 3 Proposed screen-and-treat algorithm for cryptococcal antigenaemia [194•]

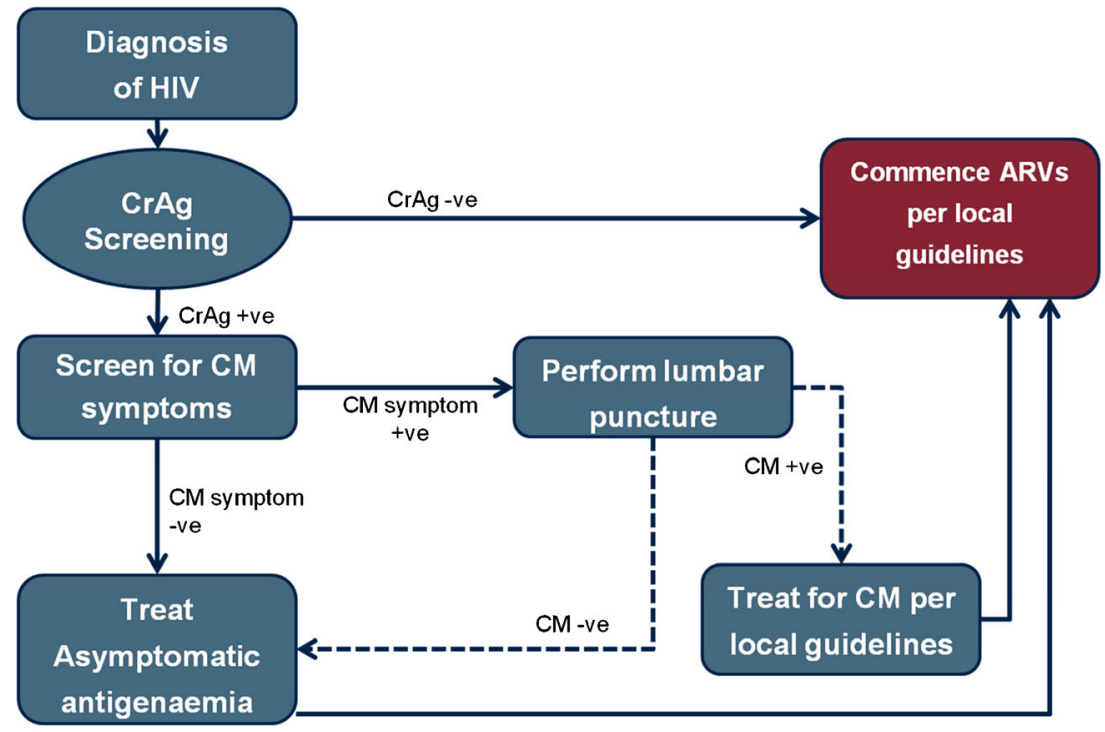

fluconazole monotherapy even if meningitis was diagnosedmortality was high in CM patients, and inadequate drug therapy may have masked any mortality gains from early diagnosis, even though the proposed benefit from preventing cases of $\mathrm{CM}$ should have been realized.

Cryptococcal infections are challenging to manage, and there is a value in considering the story of the scientific response when considering how to respond to future emerging infections. Firstly, the diagnostic tests and treatments must be available where the burden of disease is highest, and ideally, research should be undertaken in these settings [198]. Secondly, trials should be powered for relevant clinical endpoints until surrogate endpoints have been conclusively validated. Finally, it shows the importance of having proposed preventative medicine interventions such as early initiation of ARVs and pre-symptomatic screening trialed in a robust, real-world setting before they are rolled out, as results can be unexpected.

\section{Conclusion}

Cryptococcus spp. are considered model yeasts for a variety of reasons: disease is relatively easy to diagnose; a wide-variety of laboratory models of infection have been developed; organisms are convenient to keep and grow in laboratory environments; and they are well characterized as a result of their major public health impact and disease is severe, so the impact of an intervention is readily measured.

Cryptococcosis remains a challenging condition which is unlikely to go away whilst populations of iatrogenically immunosuppressed hosts increase and the pathogen itself continues to adapt to new environments and hosts. The high mortality associated with best available treatment demands that further therapeutic trials are undertaken with new antifungals or adjuvants. Adaptive trial designs and international collaborations should allow these to be powered to clinically relevant endpoints until such a time as surrogate endpoints have been validated.

A further ongoing focus should be systems-based approaches to earlier diagnosis, such as LFA screening - but these must be clearly evaluated for benefits in real-world settings. As cryptococcal disease continues to emerge; ongoing research should see the development of models and approaches likely to be transferable to other pathogens in the future. Monitoring the trajectory of its adaptations to new environments and new hosts will allow health care planners to consider its likely future impact. Together, these measures will hopefully address the unacceptably high global mortality and morbidity associated with this model CNS pathogen.

Open Access This article is distributed under the terms of the Creative Commons Attribution 4.0 International License (http:// creativecommons.org/licenses/by/4.0/), which permits unrestricted use, distribution, and reproduction in any medium, provided you give appropriate credit to the original author(s) and the source, provide a link to the Creative Commons license, and indicate if changes were made.

\section{References}

Papers of particular interest, published recently, have been highlighted as:

- Of importance

1. Park BJ, Wannemuehler KA, Marston BJ, Govender N, Pappas PG, Chiller TM. Estimation of the current global burden of cryptococcal meningitis among persons living with HIV/AIDS. AIDS [Internet]. 2009 Feb 20 [cited 2013 Feb 6]; 23(4):525-30. Available from: http://www.ncbi.nlm.nih.gov/pubmed/19182676. 
2. Brizendine KD, Baddley JW, Pappas PG. Predictors of mortality and differences in clinical features among patients with Cryptococcosis according to immune status. PLoS One [Internet]. 2013 Jan [cited 2014 Nov 7];8(3):e60431. Available from: http://www.pubmedcentral.nih.gov/articlerender.fcgi? artid $=3608592$ \& tool $=$ pmcentrez\&rendertype $=$ abstract.

3. Pyrgos V, Seitz AE, Steiner CA, Prevots DR, Williamson PR. Epidemiology of cryptococcal meningitis in the US: 1997-2009. PLoS One [Internet]. 2013 Jan [cited 2014 Nov 7];8(2):e56269. Available from: http://www.pubmedcentral.nih.gov/articlerender. fcgi? artid $=3574138 \&$ tool $=$ pmcentrez\&rendertype $=$ abstract.

4. Casadevall A, Perfect JR. Cryptococcus neoformans. 1st ed. Washington: Washington, DC: American Society for Microbiology; 1998.

5. Ellis DH, Pfeiffer TJ. Natural habitat of Cryptococcus neoformans var. gattii. J Clin Microbiol [Internet]. 1990 Jul [cited 2014 Dec 17];28(7):1642-4. Available from: http://www.ncbi.nlm.nih.gov/ pubmed/268004.

6. Ellis DH, Pfeiffer TJ. Ecology, life cycle, and infectious propagule of Cryptococcus neoformans. Lancet [Internet]. 1990 Oct 13;336(8720):923-5. Available from: http:/www.ncbi.nlm.nih. gov/pubmed/1976940.

7. Litvintseva AP, Carbone I, Rossouw J, Thakur R, Nelesh P, Mitchell TG. Evidence that the human pathogenic fungus Cryptococcus neoformans var. grubii may have evolved in Africa. PLoS Med. 2011; 6(5).

8. Chowdhary A, Rhandhawa HS, Prakash A, Meis JF. Environmental prevalence of Cryptococcus neoformans and Cryptococcus gattii in India: an update. Crit Rev Microbiol [Internet]. 2012 Feb [cited 2013 Nov 18]; 38(1):1-16. Available from: http://www.ncbi.nlm.nih.gov/pubmed/22133016.

9. Kidd SE, Chow Y, Mak S, Bach PJ, Chen H, Hingston AO, et al. Characterization of environmental sources of the human and animal pathogen Cryptococcus gattii in British Columbia, Canada, and the pacific northwest of the United States. Appl Environ Microbiol [Internet]. 2007 Mar [cited 2013 Feb 1];73(5):143343. Available from: http://www.pubmedcentral.nih.gov/ articlerender.fcgi?artid=1828779\&tool=pmcentrez\&rendertype $=$ abstract.

10. Heitman J, Kozel TR, Kwon-chung KJ, Perfect JR, Casadevall A. Cryptococcus from human pathogen to model yeast. Washington: ASM Press; 2011.

11. Chau TT, Mai NH, Phu NH, Nghia HD, Chuong LV, Sinh DX, et al. A prospective descriptive study of cryptococcal meningitis in HIV uninfected patients in Vietnam - high prevalence of Cryptococcus neoformans var grubii in the absence of underlying disease. BMC Infect Dis [Internet]. 2010 Jan [cited 2015 Jan 13];10:199. Available from: http://www.pubmedcentral.nih.gov/ articlerender.fcgi? artid $=2910700 \&$ tool $=$ pmcentrez\&rendertype $=$ abstract.

12. Chen J, Varma A, Diaz MR, Litvintseva AP, Wollenberg KK, Kwon-Chung KJ. Cryptococcus neoformans strains and infection in apparently immunocompetent patients, China. Emerg Infect Dis [Internet]. 2008 May [cited 2014 Dec 12];14(5):755-62. Available from: http://www.pubmedcentral.nih.gov/articlerender.fcgi?artid= 2600263\&tool $=$ pmcentrez\&rendertype $=$ abstract.

13. Sanfelice F. Contributo alla morfologia e biologia dei blastomiceti che si sviluppano nei succhi di alcuni frutti. [Contribution to the morphology and biology of blastomycetes that develop in some fruit juices]. Ann Ig R Univ Roma. 1894;4:463-95.

14. Sanfelice F. Sull'azione patogena dei blastomiceti. I [On the pathogenic action of blastomycetes. I]. Ann Ig R Univ Roma. 1894;5: 239-62.

15. Busse O. Über parasitäre Zelleinschlüsse und ihre Züchtung. [About parasitic cell inclusions and their breeding]. Zentralbl Bakteriol. 1894;16:175-80.
16. Benham R. Cryptococci - their identification by morphology and by serology. J Infect Dis [Internet]. 1935 [cited 2014 Nov 13];57(3):255-74. Available from: http://jid.oxfordjournals.org/ content $/ 57 / 3 / 255$.full.pdf.

17. Evans E. The antigenic composition of Cryptococcus neoformans. I. A serologic classification by means of the capsular and agglutination reactions. J Immunol [Internet]. 1950 [cited 2014 Nov 13]; Available from: http://www.cabdirect.org/abstracts/19502703633. html.

18. Evans E, Kessel J. The antigenic composition of Cryptococcus neoformans II. Serologic studies with the capsular polysaccharide. J Immunol [Internet]. 1951 [cited 2014 Nov 13]; Available from: http://www.jimmunol.org/content/67/2/109.short.

19. Wilson D, Bennett J, Bailey J. Serologic grouping of Cryptococcus neoformans. Exp Biol ... [Internet]. 1968 [cited 2014 Nov 28];(32812):821-2. Available from: http://ebm. sagepub.com/content/127/3/820.short.

20. Ikeda R, Nishikawa A. Chemical characterization of capsular polysaccharide from Cryptococcus neoformans Serotype A-D. Microbiol ... [Internet]. 1985 [cited 2014 Nov 13];29(10):98191. Available from: http://onlinelibrary.wiley.com/doi/10.1111/j. 1348-0421.1985.tb02962.x/abstract.

21. Kwon-Chung KJ, Varma A. Do major species concepts support one, two or more species within Cryptococcus neoformans? FEMS Yeast Res [Internet]. 2006 Jun [cited 2013 Feb 6];6(4): 574-87. Available from: http://www.ncbi.nlm.nih.gov/pubmed/ 16696653.

22. Meyer W, Castañeda A, Jackson S, Huynh M, Castañeda E. Molecular typing of IberoAmerican Cryptococcus neoformans isolates. Emerg Infect Dis [Internet]. 2003 Feb;9(2):189-95. Available from: http://www.pubmedcentral.nih.gov/articlerender. fcgi?artid $=2901947 \&$ tool $=$ pmcentrez\&rendertype $=$ abstract.

23. Boekhout T, Theelen B, Diaz M, Fell JW, Hop WC, Abeln EC, et al. Hybrid genotypes in the pathogenic yeast Cryptococcus neoformans. Microbiology [Internet]. 2001 Apr;147(Pt 4):891907. Available from: http://www.ncbi.nlm.nih.gov/pubmed/ 11283285.

24. Litvintseva AP, Thakur R, Vilgalys R, Mitchell TG. Multilocus sequence typing reveals three genetic subpopulations of Cryptococcus neoformans var. grubii (serotype A), including a unique population in Botswana. Genetics [Internet]. $2006 \mathrm{Apr}$ [cited 2013 Feb 6];172(4):2223-38. Available from: http://www. pubmedcentral.nih.gov/articlerender.fcgi?artid $=1456387 \&$ tool $=$ pmcentrez\&rendertype $=$ abstract.

25. Kwon-chung KJ, Boekhout T, Fell JW, Diaz M. (1557) Proposal to conserve the name Cryptococcus gattii against $\mathrm{C}$. honduri- anus and C. bacillisporus (Basidiomycota, Hymenomycetes, Tremellomycet- idae). 2002;806(November):804-6.

26. Chen SC, Meyer W, Sorrell TC. Cryptococcus gattii Infections. Clin Microbiol Rev [Internet]. 2014 Oct [cited 2014 Oct 7];27(4): 980-1024. Available from: http://www.ncbi.nlm.nih.gov/pubmed/ 25278580. Detailed and comprehensive review of C. gattii infections.

27. Xu J, Vilgalys R, Mitchell T. Multiple gene genealogies reveal recent dispersion and hybridization in the human pathogenic fungus Cryptococcus neoformans. Mol Ecol [Internet]. 2000 [cited 2014 Nov 25];1471-81. Available from: http://onlinelibrary.wiley. com/doi/10.1046/j.1365-294x.2000.01021.x/full.

28. Butler MI, Poulter RTM. The PRP8 inteins in Cryptococcus are a source of phylogenetic and epidemiological information. Fungal Genet Biol [Internet]. 2005 May [cited 2014 Nov 18];42(5):45263. Available from: http://www.sciencedirect.com/science/article/ pii/S1087184505000228.

29. Ngamskulrungroj P, Gilgado F, Faganello J, Litvintseva AP, Leal $\mathrm{AL}$, Tsui KM, et al. Genetic diversity of the Cryptococcus species complex suggests that Cryptococcus gattii deserves to have 
varieties. PLoS One [Internet]. 2009 Jan [cited 2013 Feb 6];4(6): e5862. Available from: http://www.pubmedcentral.nih.gov/ articlerender.fcgi? artid $=2690690 \&$ tool $=$ pmcentrez\&rendertype $=$ abstract.

30. Sharpton TJ, Neafsey DE, Galagan JE, Taylor JW. Mechanisms of intron gain and loss in Cryptococcus. Genome Biol. 2008;9(1):R24.

31. Trilles L, Meyer W, Wanke B, Guarro J, Lazéra M. Correlation of antifungal susceptibility and molecular type within the Cryptococcus neoformans/C. gattii species complex. Med Mycol [Internet]. 2012 Apr [cited 2015 Jan 6];50(3):328-32. Available from: http://www.ncbi.nlm.nih.gov/pubmed/21859388.

32. Byrnes EJ, Li W, Lewit Y, Ma H, Voelz K, Ren P, et al. Emergence and pathogenicity of highly virulent Cryptococcus gattii genotypes in the northwest United States. PLoS Pathog. 2010;6(4): e1000850.

33. Bovers M, Hagen F, Kuramae EE, Boekhout T. Six monophyletic lineages identified within Cryptococcus neoformans and Cryptococcus gattii by multi-locus sequence typing. Fungal Genet Biol [Internet]. 2008 Apr [cited 2013 Feb 4];45(4):40021. Available from: http://www.ncbi.nlm.nih.gov/pubmed/ 18261945.

34. Springer DJ, Billmyre RB, Filler EE, Voelz K, Pursall R, Mieczkowski $\mathrm{P}$ a, et al. Cryptococcus gattii VGIII isolates causing infections in HIV/AIDS patients in Southern California: identification of the local environmental source as arboreal. PLoS Pathog [Internet]. 2014 Aug [cited 2014 Nov 25];10(8):e1004285. Available from: http://www.pubmedcentral.nih.gov/articlerender. fcgi artid $=4140843 \&$ tool $=$ pmcentrez\&rendertype $=$ abstract . Describes a non-random environmental sampling approach based on collecting samples from sites of known infections using this method the investigators identified new environmental niches for VGIII in California. Prior to this paper, it was seldom found in the environment, despite appearing frequently in clinical samples.

35. Shenoy B, Jeewon R, Hyde K. Impact of DNA sequence-data on the taxonomy of anamorphic fungi. Fungal Divers [Internet]. 2007 [cited 2014 Nov 26];1-54. Available from: http:/www.academia. edu/download/30869325/8gk6B.pdf.

36. Kwon-Chung KJ, Polacheck I, Bennett JE. Improved diagnostic medium for separation of Cryptococcus neoformans var. neoformans (serotypes A and D) and Cryptococcus neoformans var. gattii (serotypes B and C). J Clin Microbiol [Internet]. 1982 Mar [cited 2015 Jan 20];15(3):535-7. Available from: http://www. pubmedcentral.nih.gov/articlerender.fcgi?artid $=272134 \&$ tool $=$ pmcentrez\&rendertype $=$ abstract

37. Hata DJ, Hall L, Fothergill AW, Larone DH, Wengenack NL. Multicenter evaluation of the new VITEK 2 advanced colorimetric yeast identification card. J Clin Microbiol [Internet]. 2007 Apr [cited 2014 Dec 19];45(4):1087-92. Available from: http://www. pubmedcentral.nih.gov/articlerender.fcgi?artid $=1865816 \&$ tool $=$ pmcentrez\&rendertype $=$ abstract.

38. Brown SM, Campbell LT, Lodge JK. Cryptococcus neoformans, a fungus under stress. Curr Opin Microbiol [Internet]. 2007 Aug [cited 2014 Nov 26];10(4):320-5. Available from: http://www. sciencedirect.com/science/article/pii/S1369527407000811.

39. Doyle S. Fungal proteomics: from identification to function. FEMS Microbiol Lett [Internet]. 2011 Aug [cited 2014 Nov 4];321(1):1-9. Available from: http://www.ncbi.nlm.nih.gov/ pubmed/21517945.

40. Croxatto A, Prod'hom G, Greub G. Applications of MALDI-TOF mass spectrometry in clinical diagnostic microbiology. FEMS Microbiol Rev [Internet]. 2012 Mar [cited 2014 Oct 8];36(2): 380-407. Available from: http://www.ncbi.nlm.nih.gov/pubmed/ 22092265.
41. Missall TA, Pusateri ME, Lodge JK. Thiol peroxidase is critical for virulence and resistance to nitric oxide and peroxide in the fungal pathogen, Cryptococcus neoformans. Mol Microbiol [Internet]. Blackwell Science Ltd; 2004 Mar 1 [cited 2014 Nov 26];51(5):1447-58. Available from: http://onlinelibrary.wiley. com/doi/10.1111/j.1365-2958.2004.03921.x/full.

42. Missall TA, Pusateri ME, Donlin MJ, Chambers KT, Corbett JA, Lodge JK. Posttranslational, translational, and transcriptional responses to nitric oxide stress in Cryptococcus neoformans: implications for virulence. Eukaryot Cell [Internet]. 2006 Mar [cited 2014 Nov 26];5(3):518-29. Available from: http://www. pubmedcentral.nih.gov/articlerender.fcgi?artid=1398057\&tool= pmcentrez\&rendertype $=$ abstract.

43. Szopinska A, Morsomme P. Quantitative proteomic approaches and their application in the study of yeast stress responses. OMICS [Internet]. 2010 Dec [cited 2013 Feb 6];14(6):639-49. Available from: http://www.ncbi.nlm.nih.gov/pubmed/20695824.

44. - Santi L, Beys-da-Silva WO, Berger M, Calzolari D, Guimarães JA, Moresco JJ, et al. Proteomic profile of Cryptococcus neoformans biofilm reveals changes in metabolic processes. J Proteome Res [Internet]. 2014 Mar 7 [cited 2015 Jan 26];13(3): 1545-59. Available from: http://pubs.acs.org/doi/abs/10.1021/ pr401075f. Demonstrates the potential value of proteomics in assessing dynamic behaviour in human pathogens. The investigators are able to suggest metabolic pathways adopted by cells in their biofilm form, and this may lead to new drug targets. Cryptococcal biofilms may significantly complicate the treatment of patients with foreign bodies.

45. Chong HS, Campbell L, Padula MP, Hill C, Harry E, Li SS, et al. Time-course proteome analysis reveals the dynamic response of Cryptococcus gattii cells to fluconazole. PLoS One [Internet]. 2012 Jan [cited 2014 Nov 27];7(8):e42835. Available from: http://www.pubmedcentral.nih.gov/articlerender.fcgi?artid= 3412811\&tool= pmcentrez\&rendertype $=$ abstract.

46. Chan M, Lye D, Win MK, Chow A, Barkham T. Clinical and microbiological characteristics of cryptococcosis in Singapore: predominance of Cryptococcus neoformans compared with Cryptococcus gattii. Int J Infect Dis [Internet]. International Society for Infectious Diseases; 2014 Sep [cited 2014 Nov 4];26:110-5. Available from: http://www.ncbi.nlm.nih.gov/ pubmed/25018090.

47. Pappas PG. Cryptococcal infections in non-HIV-infected patients. Trans Am Clin Climatol Assoc [Internet]. 2013 Jan [cited 2014 Nov 28];124:61-79. Available from: http://www.pubmedcentral. nih.gov/articlerender.fcgi? artid $=3715903 \&$ tool $=$ pmcentrez\&rendertype $=$ abstract.

48. Zhu L-P, Wu J-Q, Xu B, Ou X-T, Zhang Q-Q, Weng X-H. Cryptococcal meningitis in non-HIV-infected patients in a Chinese tertiary care hospital, 1997-2007. Med Mycol [Internet]. 2010 Jun [cited 2013 Feb 6];48(4):570-9. Available from: http:// www.ncbi.nlm.nih.gov/pubmed/20392150.

49. Mirza SA, Phelan M, Rimland D, Graviss E, Hamill R, Brandt ME, et al. The changing epidemiology of cryptococcosis: an update from population-based active surveillance in 2 large metropolitan areas, 1992-2000. Clin Infect Dis. 2003;36(6):789-94.

50. Tintelnot K, Lemmer K, Losert H, Schär G, Polak A. Follow-up of epidemiological data of cryptococcosis in Austria, Germany and Switzerland with special focus on the characterization of clinical isolates [Fortfuhrung der Datenerhebung zur Cryptococcose in Osterreich, Deutschland und der Schweiz unter beson. Mycoses [Internet]. 2004 [cited 2014 Nov 29];(September 2003):455-64. Available from: http://onlinelibrary.wiley.com/doi/10.1111/j. 1439-0507.2004.01072.x/full.

51. Nguyen MH, Husain S, Clancy CJ, Peacock JE, Hung C-C, Kontoyiannis DP, et al. Outcomes of central nervous system cryptococcosis vary with host immune function: results from a multi- 
center, prospective study. J Infect [Internet]. Elsevier Ltd; 2010 Nov [cited 2013 Nov 18];61(5):419-26. Available from: http:/ www.ncbi.nlm.nih.gov/pubmed/20732350.

52. Pappas PG, Alexander BD, Andes DR, Hadley S, Kauffman CA, Freifeld A, et al. Invasive fungal infections among organ transplant recipients: results of the Transplant-Associated Infection Surveillance Network (TRANSNET). Clin Infect Dis [Internet]. 2010 Apr 15 [cited 2014 Oct 17];50(8):1101-11. Available from: http://www.ncbi.nlm.nih.gov/pubmed/20218876.

53. Hage C, Wood H, Winer-Muram S, Wilson G, Knox K. Pulmonary cryptococcosis after initiation of anti-tumor necrosis factor- $\alpha$ therapy. CHEST ... [Internet]. 2003 [cited 2014 Nov 28];2395-7. Available from: http://journal.publications.chestnet. org/article.aspx?articleid=1082097.

54. Sun H-Y, Wagener MM, Singh N. Cryptococcosis in solid-organ, hematopoietic stem cell, and tissue transplant recipients: evidencebased evolving trends. Clin Infect Dis [Internet]. 2009 Jun 1 [cited 2013 Feb 6];48(11):1566-76. Available from: http://www.ncbi. nlm.nih.gov/pubmed/19402789.

55. Litvintseva AP, Lin X, Templeton I, Heitman J, Mitchell TG. Many globally isolated AD hybrid strains of Cryptococcus neoformans originated in Africa. PLoS Pathog [Internet]. 2007 Aug 17 [cited 2013 Feb 6];3(8):e114. Available from: http:/ www.pubmedcentral.nih.gov/articlerender.fegi?artid= 1949410\&tool=pmcentrez\&rendertype $=$ abstract.

56. Wolfe ND, Dunavan CP, Diamond J. Origins of major human infectious diseases. Nature [Internet]. Nature Publishing Group; 2007 May 17 [cited 2014 Dec 3];447(7142):279-83. Available from: http://ezproxy-prd.bodleian.ox.ac.uk:2076/nature/journal/ v447/n7142/full/nature05775.html.

57. Simwami SP, Khayhan K, Henk DA, Aanensen DM, Boekhout T, Hagen F, et al. Low diversity Cryptococcus neoformans variety grubii multilocus sequence types from Thailand are consistent with an ancestral African origin. PLoS Pathog [Internet]. 2011 Apr [cited 2013 Feb 6];7(4):e1001343. Available from: http:// www.pubmedcentral.nih.gov/articlerender.fcgi?artid= 3089418\&tool=pmcentrez\&rendertype $=$ abstract.

58. Liu H, Prugnolle F, Manica A, Balloux F. A geographically explicit genetic model of worldwide human-settlement history. Am J Hum Genet [Internet]. 2006 Aug [cited 2014 Dec 7];79(2):230-7. Available from: http://www.ncbi.nlm.nih.gov/pubmed/1559480.

59. Blasco R, Finlayson C, Rosell J, Marco AS, Finlayson S, Finlayson G, et al. The earliest pigeon fanciers. Sci Rep [Internet]. 2014 Jan [cited 2014 Nov 24];4:5971. Available from: http://www.pubmedcentral.nih.gov/articlerender.fcgi?artid= 4124739\&tool=pmcentrez\&rendertype $=$ abstract.

60. Nielsen K, De Obaldia AL, Heitman J. Cryptococcus neoformans mates on pigeon guano: implications for the realized ecological niche and globalization. Eukaryot Cell [Internet]. 2007 Jun [cited 2013 Feb 6];6(6):949-59. Available from: http://www. pubmedcentral.nih.gov/articlerender.fcgi?artid $=1951517 \&$ tool $=$ pmcentrez\&rendertype $=$ abstract

61. Moodley Y, Linz B, Bond RP, Nieuwoudt M, Soodyall H, Schlebusch CM, et al. Age of the association between Helicobacter pylori and man. PLoS Pathog [Internet]. 2012 Jan [cited 2014 Nov 24];8(5):e1002693. Available from: http://www. pubmedcentral.nih.gov/articlerender.fcgi?artid $=3349757 \&$ tool $=$ pmcentrez\&rendertype $=$ abstract.

62. Falush D, Wirth T, Linz B, Pritchard JK, Stephens M, Kidd M, et al. Traces of human migrations in Helicobacter pylori populations. Science [Internet]. 2003 Mar 7 [cited 2014 Dec 8];299(5612):1582-5. Available from: http://www.sciencemag. org/content/299/5612/1582.short.

63. Franzot SP, Hamdan JS, Currie BP, Casadevall A. Molecular epidemiology of Cryptococcus neoformans in Brazil and the United States: evidence for both local genetic differences and a global clonal population structure. J Clin Microbiol [Internet]. 1997 Sep;35(9):2243-51. Available from: http://www.pubmedcentral. nih.gov/articlerender.fcgi?artid $=229947 \&$ tool $=$ pmcentrez\&rendertype $=$ abstract.

64. Hiremath SS, Chowdhary A, Kowshik T, Randhawa HS, Sun S, $\mathrm{Xu}$ J. Long-distance dispersal and recombination in environmental populations of Cryptococcus neoformans var. grubii from India. Microbiology [Internet]. 2008 May [cited 2013 Feb 6];154(Pt 5): 1513-24. Available from: http://www.ncbi.nlm.nih.gov/pubmed/ 18451060.

65. Sharpton TJ, Neafsey DE, Galagan JE, Taylor JW. Mechanisms of intron gain and loss in Cryptococcus. Genome Biol [Internet]. 2008 Jan [cited 2014 Dec 12];9(1):R24. Available from: http:// www.pubmedcentral.nih.gov/articlerender.fcgi? artid= 2395259\&tool $=$ pmcentrez\&rendertype $=$ abstract.

66. Vanbreuseghem R, Takashio M. An atypical strain of Cryptococcus neoformans (San Felice) Vuillemin 1894. II. Cryptococcus neoformans var. gattii var. nov. Ann Soc Belges Med Trop Parasitol Mycol [Internet]. 1970 Jan [cited 2014 Dec 17];50(6):695-702. Available from: http://www.ncbi.nlm.nih. gov/pubmed/5519205.

67. Gatti F, Eeckels R. An atypical strain of Cryptococcus neoformans (San Felice) Vuillemin 1894. I. Description of the disease and of the strain. Ann Soc Belges Med Trop Parasitol Mycol [Internet]. 1970 Jan [cited 2014 Dec 17];50(6):689-93. Available from: http://www.ncbi.nlm.nih.gov/pubmed/5519205.

68. Ellis DH, Pfeiffer TJ. Natural habitat of Cryptococcus neoformans var. gattii. J Clin Microbiol. 1990;28(7):1642-4.

69. Trilles L, Lazéra M, Wanke B, Theelen B, Boekhout T. Genetic characterization of environmental isolates of the Cryptococcus neoformans species complex from Brazil. Med Mycol [Internet]. 2003 Jan [cited 2013 Feb 6];41(5):383-90. Available from: http:// informahealthcare.com/doi/abs/10.1080/1369378031000137206.

70. Refojo N, Perrotta D, Brudny M, Abrantes R, Hevia a I, Davel G. Isolation of Cryptococcus neoformans and Cryptococcus gattii from trunk hollows of living trees in Buenos Aires City, Argentina. Med Mycol [Internet]. 2009 Mar [cited 2013 Nov 18];47(2):177-84. Available from: http://www.ncbi.nlm.nih.gov/ pubmed/18654914.

71. Granados DP, Castañeda E. Isolation and characterization of Cryptococcus neoformans varieties recovered from natural sources in Bogotá, Colombia, and study of ecological conditions in the area. Microb Ecol [Internet]. 2005 Feb [cited 2013 Feb 6];49(2):282-90. Available from: http://www.ncbi.nlm.nih.gov/ pubmed/15965721.

72. Lazera MS, Salmito Cavalcanti MA, Londero AT, Trilles L, Nishikawa MM, Wanke B. Possible primary ecological niche of Cryptococcus neoformans. Med Mycol [Internet]. 2000 Oct;38(5):379-83. Available from: http://www.ncbi.nlm.nih.gov/ pubmed/11092385.

73. Fortes ST, Lazéra MS, Nishikawa MM, Macedo RC, Wanke B. First isolation of Cryptococcus neoformans var. gattii from a native jungle tree in the Brazilian Amazon rainforest. Mycoses [Internet]. 2001 Jan [cited 2014 Dec 18];44(5):137-40. Available from: http://www.ncbi.nlm.nih.gov/pubmed/11486449.

74. Chen S, Sorrell T, Nimmo G, Speed B, Currie B, Ellis D, et al. Epidemiology and host- and variety-dependent characteristics of infection due to Cryptococcus neoformans in Australia and New Zealand. Australasian Cryptococcal Study Group. Clin Infect Dis [Internet]. 2000 Aug [cited 2014 Dec 5];31(2):499-508. Available from: http://cid.oxfordjournals.org/content/31/2/499.short.

75. Galanis E, Hoang L, Kibsey P, Morshed M, Phillips P. Clinical presentation, diagnosis and management of Cryptococcus gattii cases: Lessons learned from British Columbia. Can J Infect Dis Med Microbiol [Internet]. 2009 Jan [cited 2014 Dec 16];20(1):238. Available from: http://www.pubmedcentral.nih.gov/ 
articlerender.fcgi?artid $=2690522 \&$ tool $=$ pmcentrez\&rendertype $=$ abstract.

76. Chen SC-A, Slavin MA, Heath CH, Playford EG, Byth K, Marriott D, et al. Clinical manifestations of Cryptococcus gattii infection: determinants of neurological sequelae and death. Clin Infect Dis [Internet]. 2012 Sep [cited 2014 Dec 16];55(6):789-98. Available from: http://www.ncbi.nlm.nih.gov/pubmed/22670042.

77. Galanis E. Epidemiology of Cryptococcus gattii, British Columbia, Canada, 1999-2007. Emerg Infect Dis [Internet]. 2010 Feb [cited 2014 Dec 11];16(2):251-7. Available from: http://www.cdc.gov/eid/content/16/2/251.htm.

78. Hagen F, Colom MF, Swinne D, Tintelnot K, Iatta R, Montagna MT, et al. Autochthonous and dormant Cryptococcus gattii infections in Europe. Emerg Infect Dis [Internet]. 2012 Oct [cited 2015 Jan 3];18(10):1618-24. Available from: http://www. pubmedcentral.nih.gov/articlerender.fcgi?artid=3471617\&tool= pmcentrez\&rendertype $=$ abstract.

79. Cogliati M. Global molecular epidemiology of Cryptococcus neoformans and Cryptococcus gattii: An Atlas of the Molecular Types. Scientifica (Cairo) [Internet]. 2013 Jan [cited 2015 Jan 14];2013. Available from: http://www.pubmedcentral.nih.gov/ articlerender.fcgi? artid $=3820360 \&$ tool $=$ pmcentrez\&rendertype $=$ abstract.

80. Byrnes EJ, Bildfell RJ, Frank S a, Mitchell TG, Marr K a, Heitman $\mathrm{J}$. Molecular evidence that the range of the Vancouver Island outbreak of Cryptococcus gattii infection has expanded into the Pacific Northwest in the United States. J Infect Dis [Internet]. 2009 Apr 1 [cited 2014 Dec 3];199(7):1081-6. Available from: http://www.pubmedcentral.nih.gov/articlerender.fcgi?artid= 2715219\&tool=pmcentrez\&rendertype $=$ abstract.

81. Voelz K, Johnston SA, Smith LM, Hall RA, Idnurm A, May RC. "Division of labour" in response to host oxidative burst drives a fatal Cryptococcus gattii outbreak. Nat Commun [Internet]. Nature Publishing Group; 2014 Jan [cited 2015 Jan 3];5:5194. Available from: http://www.pubmedcentral.nih.gov/articlerender.fcgi?artid= $4208095 \&$ tool $=$ pmcentrez\&rendertype $=$ abstract. First description of the mechanism linking alterations in cryptococcal mitochondrial morphology with pathophysiology and suggesting a role for signaling between yeast cells. May help to explain the increased pathogenicity seen in the Vancouver Island outbreak strains.

82. Ngamskulrungroj P, Serena C, Gilgado F, Malik R, Meyer W. Global VGIIa isolates are of comparable virulence to the major fatal Cryptococcus gattii Vancouver Island outbreak genotype. Clin Microbiol Infect [Internet]. 2011 Feb [cited 2014 Dec 18];17(2):251-8. Available from: http://www.ncbi.nlm.nih.gov/ pubmed/20331682.

83. Lockhart SR, Iqbal N, Harris JR, Grossman NT, DeBess E, Wohrle $\mathrm{R}$, et al. Cryptococcus gattii in the United States: genotypic diversity of human and veterinary isolates. PLoS One [Internet]. 2013 Jan [cited 2014 Dec 18];8(9):e74737. Available from: http://www. pubmedcentral.nih.gov/articlerender.fcgi?artid $=3760847 \&$ tool $=$ pmcentrez\&rendertype $=$ abstract. Helps to resolve questions about the ancestral origins Cryptococcus gattii and describes possible global flows for the pathogen.

84. Hagen F, Ceresini PC, Polacheck I, Ma H, van Nieuwerburgh F, Gabaldón T, et al. Ancient dispersal of the human fungal pathogen Cryptococcus gattii from the Amazon rainforest. PLoS One [Internet]. 2013 Jan [cited 2014 Dec 12];8(8):e71148. Available from: http:/www.pubmedcentral.nih.gov/articlerender.fcgi?artid= $3737135 \&$ tool $=$ pmcentrez\&rendertype $=$ abstract.

85. Mak S, Klinkenberg B, Bartlett K, Fyfe M. Ecological niche modeling of Cryptococcus gattii in British Columbia, Canada. Environ Health Perspect [Internet]. 2010 May [cited 2015 Jan 6];118(5):653-8. Available from: http://www.pubmedcentral.nih. gov/articlerender.fcgi? artid=2866681\&tool= pmcentrez\&rendertype $=$ abstract.

86. Steenbergen JN, Casadevall A. The origin and maintenance of virulence for the human pathogenic fungus Cryptococcus neoformans. Microbes Infect. 2003;5:667-75.

87. Casadevall A, Steenbergen JN, Nosanchuk JD. "Ready made" virulence and "dual use" virulence factors in pathogenic environmental fungi- the Cryptococcus neoformans paradigm. Curr Opin Microbiol. 2003;6(4):332-7.

88. Kronstad JW, Attarian R, Cadieux B, Choi J, D’Souza CA, Griffiths EJ, et al. Expanding fungal pathogenesis: Cryptococcus breaks out of the opportunistic box. Nat Rev Microbiol [Internet]. Nature Publishing Group; 2011 Mar [cited 2013 Feb 6];9(3):193203. Available from: http://www.ncbi.nlm.nih.gov/pubmed/ 21326274

89. Lin X, Heitman J. The biology of the Cryptococcus neoformans species complex. Annu Rev Microbiol [Internet]. 2006 Jan [cited 2013 Feb 6];60:69-105. Available from: http://www.ncbi.nlm.nih. gov/pubmed/16704346.

90. Ruiz A, Neilson JB, Bulmer GS, Box PO, City O, Rico P, et al. Control of Cryptococcus neoformans in nature by biotic factors. Sabouraudia. 1982;20:21-9.

91. Steenbergen JN, Shuman HA, Casadevall A. Cryptococcus neoformans interactions with amoebae suggest an explanation for its virulence and intracellular pathogenic strategy in macrophages. Proc Natl Acad Sci U S A. 2001;98(26):15245-50.

92. Chrisman CJ, Alvarez M, Casadevall A. Phagocytosis of Cryptococcus neoformans by, and nonlytic exocytosis from, Acanthamoeba castellanii. Appl Environ Microbiol. 2010;76(18):6056-62.

93. Zaragoza O, Rocío GR, Nosanchuk JD, Cuenca-Estrella M, Rodríguez-Tudela JL, Casadevall A. Fungal cell gigantism during mammalian infection. PLoS Pathog. 2010;6(6):e1000945.

94. Voelz K. Macrophage-cryptococcus interactions during cryptococcosis [Internet]. University of Birmingham; 2010 [cited 2015 Jan 22]. Available from: http://etheses.bham.ac.uk/1194/.

95. Nicola AM, Robertson EJ, Albuquerque P, Casadevall A. Nonlytic exocytosis of Cryptococcus neoformans from macrophages occurs in vivo and is influenced by phagosomal $\mathrm{pH}$. 2011;2(4):1-9.

96. Johnston SA, May RC. The human fungal pathogen Cryptococcus neoformans escapes macrophages by a phagosome emptying mechanism that is inhibited by Arp2/3 complex-mediated actin polymerisation. PLoS Pathog. 2010;6(8):e1001041.

97. Feldmesser M, Tucker S, Casadevall A. Intracellular parasitism of macrophages by Cryptococcus neoformans. Trends Microbiol. 2001;9(6):273-8.

98. Ma H. Intracellular parasitism of macrophages by Cryptococcus. University of Birmingham; 2009. p. 273-8.

99. Ma H, Croudace JE, Lammas DA, May RC. Expulsion of live pathogenic yeast by macrophages. Curr Biol. 2006;16(21):215660 .

100. Charlier C, Nielsen K, Daou S, Brigitte M, Chretien F, Dromer F. Evidence of a role for monocytes in dissemination and brain invasion by Cryptococcus neoformans. Infect Immun. 2009;77(1): $120-7$.

101. Alvarez M, Burn T, Luo Y, Pirofski L, Casadevall A. The outcome of Cryptococcus neoformans intracellular pathogenesis in human monocytes. BMC Microbiol. 2009;9(51):1-9.

102. Del Poeta M. Role of phagocytosis in the virulence of Cryptococcus neoformans. Eukaryot Cell. 2004;3(5):1067.

103. Sabiiti W, Robertson E, Beale MA, Johnston SA, Brouwer AE, Loyse A, et al. Efficient phagocytosis and laccase activity affect the outcome of HIV-associated cryptococcosis. J Clin Investig. 2014;124(5):2000-8. 
104. Alanio A, Desnos-Ollivier M, Dromer F. Dynamics of Cryptococcus neoformans-macrophage interactions reveal that fungal background influences outcome during cryptococcal meningoencephalitis. MBio [Internet]. 2011 [cited 2014 Dec 11]; Available from: http://mbio.asm.org/content/2/4/e00158-11.full.

105. Mansour MK, Vyas JM, Levitz SM, Virulence D, Assessment R, Pathogenesis I, et al. Dynamic virulence : real-time assessment of intracellular pathogenesis links Cryptococcus neoformans phenotype with clinical. 2011.

106. Zaragoza O, Rodrigues ML, De Jesus M, Frases S, Casadevall A, De Micología S, et al. The capsule of the fungal pathogen Cryptococcus neoformans. Adv Appl Microbiol. 2010;2164(09): $1-64$.

107. Aksenov SI, Babyeva IP, Golubev WI. On the mechanism of adaptation of micro-organisms to conditions of extreme low humidity. Life Sci Space Res. 1973;11:55-61.

108. Frases S, Nimrichter L, Viana NB, Nakouzi A, Casadevall A. Cryptococcus neoformans capsular polysaccharide and exopolysaccharide fractions manifest physical, chemical, and antigenic differences. Eukaryot Cell. 2008;7(2):319-27.

109. Robertson EJ, Najjuka G, Rolfes MA, Akampurira A, Jain N, Anantharanjit J, et al. Cryptococcus neoformans ex vivo capsule size is associated with intracranial pressure and host immune response in HIV-associated cryptococcal meningitis. J Infect Dis. 2014;209(1):74-82.

110. Fromtling RA, Shadomy HJ, Jacobson ES. Decreased virulence in stable, acapsular mutants of cryptococcus neoformans. Mycopathologia. 1982;79:23-9.

111. Wilder J, Olson G. Complementation of a capsule deficient Cryptococcus neoformans with CAP64 restores virulence in a murine lung infection. ... J Respir ... [Internet]. 2002 [cited 2014 Dec 8];(13). Available from: http://www.atsjournals.org/ doi/abs/10.1165/ajrcmb.26.3.4479.

112. Vecchiarelli A. Immunoregulation by capsular components of Cryptococcus neoformans. Med Mycol. 2000;38:407-17.

113. Almeida GM, Andrade RM, Bento CAM. The capsular polysaccharides of Cryptococcus neoformans activate normal CD4+ T cells in a dominant Th2 pattern. J Immunol. 2001;167(10):584551.

114. Casadevall A. Fungal virulence, vertebrate endothermy, and dinosaur extinction: is there a connection? Fungal Genet Biol. 2005;42(2):98-106.

115. Leach MD, Cowen LE. Surviving the heat of the moment: a fungal pathogens perspective. PLoS Pathog. 2013;9(3):e1003163.

116. Gow NAR. Fungal morphogenesis: some like it hot. Curr Biol. 2009;19(8):R333-4.

117. Perfect JR. Cryptococcus neoformans: the yeast that likes it hot. FEMS Yeast Res. 2006;6(4):463-8.

118. Martinez LR, Garcia-Rivera J, Casadevall A. Cryptococcus neoformans var. neoformans (serotype D) strains are more susceptible to heat than C. neoformans var. grubii (serotype A) strains. J Clin Microbiol. 2001;39:3365-7.

119. Garcia-solache MA, Casadevall A. Global warming will bring new fungal diseases for mammals. MBio. 2010;1(1).

120. Williamson PR, Wakamatsu K, Ito S. Melanin biosynthesis in Cryptococcus neoformans. J Bacteriol. 1998;180:1570-2.

121. Eisenman HC, Mues M, Weber SE, Frases S, Chaskes S, Gerfen $\mathrm{G}$, et al. Cryptococcus neoformans laccase catalyses melanin synthesis from both D- and L-DOPA. Microbiology. 2007;153:3954 62.

122. Williamson PR. Laccase and melanin in the pathogenesis of Cryptococcus neoformans. Front Biosci. 1997;2:e99-107.

123. Rosas ÁL, Casadevall A. Melanization affects susceptibility of Cryptococcus neoformans to heat and cold. FEMS Microbiol Lett. 1997;153:265-72.
124. Wang Y, Casadevall A. Decreased susceptibility of melanized Cryptococcus neoformans to UV light. Appl Environ Microbiol. 1994;60:3864-6.

125. Nosanchuk JD, Rudolph J, Rosas AL. Evidence that cryptococcus neoformans is melanized in pigeon excreta: implications for pathogenesis. Infect Immun. 1999;67(10):5477-9.

126. Rosas ÁL, Casadevall A. Melanization decreases the susceptibility of Cryptococcus neoformans to enzymatic degradation. Mycopathologia. 2001;151:53-6.

127. García-Rivera J, Casadevall A. Melanization of Cryptococcus neoformans reduces its susceptibility to the antimicrobial effects of silver nitrate. Med Mycol. 2001;39:353-7.

128. Ikeda R, Sugita T, Jacobson ES, Shinoda T. Effects of melanin upon susceptibility of Cryptococcus to antifungals. Microbiol Immunol. 2003;47(4):271-7.

129. Feldmesser M, Kress Y, Casadevall A. Dynamic changes in the morphology of Cryptococcus neoformans during murine pulmonary infection. Microbiology. 2001;147(Pt 8):2355-65.

130. Lin X. Cryptococcus neoformans: morphogenesis, infection, and evolution. Infect Genet Evol. 2009;9(4):401-16.

131. Zaragoza O, Fries BC, Casadevall A. Induction of capsule growth in Cryptococcus neoformans by mammalian serum and $\mathrm{CO} 2$. Infect Immun. 2003;71:6155-64.

132. Okagaki LH, Strain AK, Nielsen JN, Charlier C, Baltes NJ, Chrétien F, et al. Cryptococcal cell morphology affects host cell interactions and pathogenicity. PLoS Pathog. 2010;6(6): e1000953.

133. Idnurm A, Bahn Y-S, Nielsen K, Lin X, Fraser JA, Heitman J. Deciphering the model pathogenic fungus Cryptococcus neoformans. Nat Rev Microbiol. 2005;3(10):753-64.

134. Hsueh YP, Heitman J. Orchestration of sexual reproduction and virulence by the fungal mating-type locus. Curr Opin Microbiol. 2008;11(6):517-24.

135. D'Souza CA, Alspaugh JA, Yue C, Harashima T, Cox GM, Perfect JR, et al. Cyclic AMP-dependent protein kinase controls virulence of the fungal pathogen Cryptococcus neoformans. Mol Cell Biol. 2001;21:3179-91.

136. Love GL, Boyd GD, Greer DL. Large Cryptococcus neoformans isolated from brain abscess. J Clin Microbiol. 1985;22:1068-70.

137. Polacheck I, Lebens GA. Electrophoretic karyotype of the pathogenic yeast Cryptococcus neoformans. J Gen Microbiol. 1989;135:65-71.

138. Perfect JR, Ketabchi N, Cox GM, Ingram CW, Beiser CL. Karyotyping of Cryptococcus neoformans as an epidemiological tool. J Clin Microbiol. 1993;31:3305-9.

139. Boekhout T, Van Belkum A. Variability of karyotypes and RAPD types in genetically related strains of Cryptococcus neoformans. Curr Genet. 1997;32:203-8.

140. Boekhout T, van Belkum A, Leenders AC, Verbrugh HA, Mukamurangwa P, Swinne D, et al. Molecular typing of Cryptococcus neoformans: taxonomic and epidemiological aspects. Int J Syst Bacteriol. 1997;47:432-42.

141. Fries BC, Chen F, Currie BP, Casadevall A. Karyotype instability in Cryptococcus neoformans infection. J Clin Microbiol [Internet]. 1996 Jun [cited 2014 Dec 23];34(6):1531-4. Available from: http://www.pubmedcentral.nih.gov/articlerender.fcgi?artid= 229055\& tool=pmcentrez\&rendertype $=$ abstract.

142. Ormerod KL, Fraser JA. Balancing stability and flexibility within the genome of the pathogen Cryptococcus neoformans. Goldman WE, editor. PLoS Pathog. 2013. 9(12):e1003764.

143. Currie B, Sanati H, Ibrahim AS, Edwards JE, Casadevall A, Ghannoum MA. Sterol compositions and susceptibilities to amphotericin B of environmental cryptococcus neoformans isolates are changed by murine passage. Antimicrob Agents Chemother. 1995;39:1934-7. 
144. Cherniak R, Morris LC, Belay T, Spitzer ED, Casadevall A. Variation in the structure of glucuronoxylomannan in isolates from patients with recurrent cryptococcal meningitis. Infect Immun. 1995;63:1899-905.

145. Kavanaugh LA, Fraser JA, Dietrich FS. Recent evolution of the human pathogen Cryptococcus neoformans by intervarietal transfer of a 14-gene fragment. Mol Biol Evol. 2006;23(10):1879-90.

146. Chow EWL, Morrow CA, Djordjevic JT, Wood IA, Fraser JA. Microevolution of Cryptococcus neoformans driven by massive tandem gene amplification. Mol Biol Evol. 2012;29(8):19872000.

147. Sionov E, Lee H, Chang YC, Kwon-Chung KJ. Cryptococcus neoformans overcomes stress of azole drugs by formation of disomy in specific multiple chromosomes. PLoS Pathog [Internet]. 2010 Apr [cited 2014 Nov 6];6(4):e1000848. Available from: http://www.pubmedcentral.nih.gov/articlerender. fcgi? artid $=2848560 \&$ tool $=$ pmcentrez\&rendertype $=$ abstract.

148. Sionov E, Chang YC, Garraffo HM, Kwon-Chung KJ. Heteroresistance to fluconazole in Cryptococcus neoformans is intrinsic and associated with virulence. Antimicrob Agents Chemother. 2009;53(7):2804-15.

149. Hu G, Liu I, Sham A, Stajich JE, Dietrich FS, Kronstad JW. Comparative hybridization reveals extensive genome variation in the AIDS-associated pathogen Cryptococcus neoformans. Genome Biol. 2008;9(2):R41.

150. Selmecki A, Forche A, Berman J. Genomic plasticity of the human fungal pathogen Candida albicans. Eukaryot Cell. 2010;9(7): 991-1008.

151. Ngamskulrungroj P, Chang Y, Hansen B, Bugge C, Fischer E, Kwon-Chung KJ. Characterization of the chromosome 4 genes that affect fluconazole-induced disomy formation in Cryptococcus neoformans. PLoS One. 2012;7(3):e33022.

152. Day JN, Chau TTH, Wolbers M, Mai PP, Dung NT, Mai NH, et al. Combination antifungal therapy for cryptococcal meningitis. $\mathrm{N}$ Engl J Med [Internet]. 2013 Apr 4 [cited 2014 May 1];368(14): 1291-302. Available from: http:/www.pubmedcentral.nih.gov/ articlerender.fcgi? artid=3978204\&tool=pmcentrez\&rendertype $=$ abstract. First large randomised controlled trial powered to mortality end-point to demonstrate the superiority of amphotericin-flucytosine combination therapy in treating cryptococcal meningitis in patients with HIV.

153. Bennett JE, Dismukes WE, Duma RJ, Medoff G, Sande MA, Gallis $\mathrm{H}$, et al. A comparison of amphotericin B alone and combined with flucytosine in the treatment of cryptoccal meningitis. N Engl J Med [Internet]. 1979 Jul 19 [cited 2015 Jan 21];301(3): 126-31. Available from: http://www.ncbi.nlm.nih.gov/pubmed/ 449951.

154. Dismukes WE, Cloud G, Gallis HA, Kerkering TM, Medoff G, Craven PC, et al. Treatment of cryptococcal meningitis with combination amphotericin $\mathrm{B}$ and flucytosine for four as compared with six weeks. N Engl J Med [Internet]. 1987 Aug 6 [cited 2015 Jan 16];317(6):334-41. Available from: http://www.ncbi.nlm.nih.gov/ pubmed/3299095.

155. Van der Horst CM, Saag MS, Cloud GA, Hamill RJ, Graybill JR, Sobel JD, et al. Treatment of cryptococcal meningitis associated with the acquired immunodeficiency syndrome. National Institute of Allergy and Infectious Diseases Mycoses Study Group and AIDS Clinical Trials Group. N Engl J Med [Internet]. 1997 Jul 3 [cited 2015 Jan 6];337(1):15-21. Available from: http://www. ncbi.nlm.nih.gov/pubmed/9203426.

156. Perfect JR, Dismukes WE, Dromer F, Goldman DL, Graybill JR, Hamill RJ, et al. Clinical practice guidelines for the management of cryptococcal disease: 2010 update by the infectious diseases society of america. Clin Infect Dis [Internet]. 2010 Feb 1 [cited 2013 Feb 1];50(3):291-322. Available from: http://www.ncbi. nlm.nih.gov/pubmed/20047480.
157. Mayanja-Kizza H, Oishi K, Mitarai S, Yamashita H, Nalongo K, Watanabe K, et al. Combination therapy with fluconazole and flucytosine for cryptococcal meningitis in Ugandan patients with AIDS. Clin Infect Dis [Internet]. 1998 Jun;26(6):1362-6. Available from: http://www.ncbi.nlm.nih.gov/pubmed/9636863.

158. Nussbaum JC, Jackson A, Namarika D, Phulusa J, Kenala J, Kanyemba C, et al. Combination flucytosine and high-dose fluconazole compared with fluconazole monotherapy for the treatment of cryptococcal meningitis: a randomized trial in Malawi. Clin Infect Dis [Internet]. 2010 Feb 1 [cited 2013 Feb 6];50(3): 338-44. Available from: http://www.pubmedcentral.nih.gov/ articlerender.fcgi? artid $=2805957 \&$ tool $=$ pmcentrez\&rendertype $=$ abstract.

159. Milefchik E, Leal MA, Haubrich R, Bozzette S a, Tilles JG, Leedom JM, et al. Fluconazole alone or combined with flucytosine for the treatment of AIDS-associated cryptococcal meningitis. Med Mycol [Internet]. 2008 Jun [cited 2013 Feb 6];46(4):393-5. Available from: http://www.ncbi.nlm.nih.gov/ pubmed/18415850.

160. Loyse A, Thangaraj H, Easterbrook P, Ford N, Roy M, Chiller T, et al. Cryptococcal meningitis: improving access to essential antifungal medicines in resource-poor countries. Lancet Infect Dis [Internet]. 2013 Jul [cited 2014 Jul 3];13(7):629-37. Available from: http://www.ncbi.nlm.nih.gov/pubmed/23735626.

161. Harrison T. A phase III, randomised, controlled trial for the treatment of HIV-associated cryptococcal meningitis: oral fluconazole plus flucytosine or one week amphotericin B-based therapy vs two weeks amphotericin B-based therapy (ACTA) [Internet]. [cited 2015 Jan 21]. Available from: http://www.isrctn.com/ISRCT N45035509.

162. Pitisuttithum P, Tansuphasawadikul S, Simpson AJ, Howe PA, White NJ. A prospective study of AIDS-associated cryptococcal meningitis in Thailand treated with high-dose amphotericin B. J Infect [Internet]. 2001 Nov [cited 2014 Mar 3];43(4):226-33. Available from: http://www.ncbi.nlm.nih.gov/pubmed/11869059.

163. Bicanic T, Meintjes G, Wood R, Hayes M, Rebe K, Bekker L-G, et al. Fungal burden, early fungicidal activity, and outcome in cryptococcal meningitis in antiretroviral-naive or antiretroviralexperienced patients treated with amphotericin B or fluconazole. Clin Infect Dis [Internet]. 2007 Jul 1 [cited 2013 Feb 6];45(1):7680. Available from: http://www.ncbi.nlm.nih.gov/pubmed/ 17554704.

164. Bicanic T, Wood R, Meintjes G, Rebe K, Brouwer A, Loyse A, et al. High-dose amphotericin B with flucytosine for the treatment of cryptococcal meningitis in HIV-infected patients: a randomized trial. Clin Infect Dis [Internet]. 2008 Jul 1 [cited 2013 Feb 6];47(1):123-30. Available from: http://www.ncbi.nlm.nih.gov/ pubmed/18505387.

165. Brouwer AE, Rajanuwong A, Chierakul W, Griffin GE, Larsen RA, White NJ, et al. Combination antifungal therapies for HIVassociated cryptococcal meningitis: a randomised trial. Lancet [Internet]. 2004 May 29;363(9423):1764-7. Available from: http://www.ncbi.nlm.nih.gov/pubmed/15172774.

166. Brouwer AE, van Kan HJM, Johnson E, Rajanuwong A, Teparrukkul P, Wuthiekanun V, et al. Oral versus intravenous flucytosine in patients with human immunodeficiency virusassociated cryptococcal meningitis. Antimicrob Agents Chemother [Internet]. 2007 Mar [cited 2013 Feb 6];51(3):103842. Available from: http://www.pubmedcentral.nih.gov/ articlerender.fcgi?artid $=1803146 \&$ tool $=$ pmcentrez\&rendertype $=$ abstract.

167. Larsen RA, Bauer M, Brouwer AE, Sanchez A, Thomas AM, Rajanuwong $A$, et al. In vitro-clinical correlations for amphotericin B susceptibility in AIDS-associated cryptococcal meningitis. Antimicrob Agents Chemother [Internet]. 2007 Jan [cited 2013 Feb 6];51(1):343-5. Available from: http://www. 
pubmedcentral.nih.gov/articlerender.fcgi?artid=1797648\&tool= pmcentrez\&rendertype $=$ abstract.

168. Day J, Imran D, Ganiem AR, Tjahjani N, Wahyuningsih R, Adawiyah R, et al. CryptoDex: A randomised, double-blind, placebo-controlled phase III trial of adjunctive dexamethasone in HIV-infected adults with cryptococcal meningitis: study protocol for a randomised control trial. Trials [Internet]. 2014 Jan [cited 2014 Dec 11];15(1):441. Available from: http://www.ncbi.nlm. nih.gov/pubmed/25391338.

169. Pappas PG, Bustamante B, Ticona E, Hamill RJ, Johnson PC, Reboli A, et al. Recombinant interferon- gamma $1 \mathrm{~b}$ as adjunctive therapy for AIDS-related acute cryptococcal meningitis. J Infect Dis [Internet]. 2004 Jun 15 [cited 2015 Jan 6];189(12):2185-91. Available from: http://www.ncbi.nlm.nih.gov/pubmed/15181565.

170. Jarvis JN, Meintjes G, Rebe K, Williams GN, Bicanic T, Williams A, et al. Adjunctive interferon- $\gamma$ immunotherapy for the treatment of HIV-associated cryptococcal meningitis: a randomized controlled trial. AIDS [Internet]. 2012 Jun 1 [cited 2014 Dec 16];26(9):1105-13. Available from: http://www.pubmedcentral. nih.gov/articlerender.fcgi? artid $=3640254 \&$ tool $=$ pmcentrez\&rendertype $=$ abstract. Shows adjunctive treatment with interferon gamma can be associated with improved early fungicidal activity, which may lead to improved outcomes. Demonstrates a positive correlation between baseline interferon gamma CSF levels and subsequent rate of fungal clearance, and a negative correlation between baseline interferon gamma levels and CSF fungal burden.

171. Newton PN, Thai LH, Tip NQ, Short JM, Chierakul W, Rajanuwong A, et al. A randomized, double-blind, placebocontrolled trial of acetazolamide for the treatment of elevated intracranial pressure in cryptococcal meningitis. Clin Infect Dis [Internet]. 2002 Sep 15 [cited 2015 Jan 6];35(6):769-72. Available from: http://www.ncbi.nlm.nih.gov/pubmed/12203177.

172. Blanc F-X, Sok T, Laureillard D, Borand L, Rekacewicz C, Nerrienet E, et al. Early (2 weeks) vs. late (8 weeks) initiation of highly active antiretroviral treatment (HAART) significantly enhance survival of severely immunosuppressed HIV-infected adults with newly diagnosed tuberculosis: results of the CAME LIA clinical trial. BMC Proc [Internet]. BioMed Central Ltd; 2011 [cited 2015 Jan 21];5(Suppl 1):O11. Available from: http://www. biomedcentral.com/1753-6561/5/S1/O11.

173. Zolopa A, Andersen J, Powderly W, Sanchez A, Sanne I, Suckow $\mathrm{C}$, et al. Early antiretroviral therapy reduces AIDS progression/ death in individuals with acute opportunistic infections: a multicenter randomized strategy trial. PLoS One [Internet]. 2009 Jan [cited 2013 Mar 18];4(5):e5575. Available from: http://www. pubmedcentral.nih.gov/articlerender.fcgi?artid $=2680972 \&$ tool $=$ pmcentrez\&rendertype $=$ abstract.

174. Török ME, Yen NTB, Chau TTH, Mai NTH, Phu NH, Mai PP, et al. Timing of initiation of antiretroviral therapy in human immunodeficiency virus (HIV)-associated tuberculous meningitis. Clin Infect Dis [Internet]. 2011 Jun [cited 2014 May 1];52(11): 1374-83. Available from: http://www.ncbi.nlm.nih.gov/pubmed/ 21596680.

175. Abdool Karim SS, Naidoo K, Grobler A, Padayatchi N, Baxter C, Gray A, et al. Timing of initiation of antiretroviral drugs during tuberculosis therapy. N Engl J Med [Internet]. 2010 Feb 25;362(8):697-706. Available from: http://www.pubmedcentral. nih.gov/articlerender.fcgi? artid=3076221\&tool= pmcentrez\&rendertype $=$ abstract.

176. Boulware DR, Meya DB, Muzoora C, Rolfes MA, Huppler Hullsiek K, Musubire A, et al. Timing of antiretroviral therapy after diagnosis of Cryptococcal Meningitis. N Engl J Med [Internet]. 2014 Jun 26 [cited 2014 Jun 26];370(26):2487-98. Available from: http://www.nejm.org/doi/abs/10.1056/ NEJMoa1312884. Important trial showing early vs delayed timing of anti-retroviral therapy in cyrptococcal meningitis is associated with worse outcomes. Also interesting from the point of view of having been discontinued early.

177. Makadzange AT, Ndhlovu CE, Takarinda K, Reid M, Kurangwa $\mathrm{M}$, Gona $\mathrm{P}$, et al. Early versus delayed initiation of antiretroviral therapy for concurrent HIV infection and cryptococcal meningitis in sub-saharan Africa. Clin Infect Dis [Internet]. 2010 Jun 1 [cited 2013 Feb 6];50(11):1532-8. Available from: http://www.ncbi. nlm.nih.gov/pubmed/20415574.

178. Bisson GP, Molefi M, Bellamy S, Thakur R, Steenhoff A, Tamuhla N, et al. Early versus delayed antiretroviral therapy and cerebrospinal fluid fungal clearance in adults with HIV and cryptococcal meningitis. Clin Infect Dis [Internet]. 2013 Apr [cited 2014 Dec 23];56(8):1165-73. Available from: http://www.ncbi. nlm.nih.gov/pubmed/23362285.

179. Chang CC, Dorasamy AA, Gosnell BI, Elliott JH, Spelman T, Omarjee S, et al. Clinical and mycological predictors of cryptococcosis-associated immune reconstitution inflammatory syndrome. AIDS [Internet]. 2013 Aug 24 [cited 2014 Dec 16];27(13):2089-99. Available from: http://www.ncbi.nlm.nih. gov/pubmed/23525034.

180. Boulware DR, Bonham SC, Meya DB, Wiesner DL, Park GS, Kambugu A, et al. Paucity of initial cerebrospinal fluid inflammation in cryptococcal meningitis is associated with subsequent immune reconstitution inflammatory syndrome. $J$ Infect Dis [Internet]. 2010 Sep 15 [cited 2015 Jan 7];202(6):962-70. Available from: http://www.pubmedcentral.nih.gov/articlerender. fcgi? artid=2924457\& tool=pmcentrez\&rendertype=abstract.

181. Perfect JR, Dismukes WE, Dromer F, Goldman DL, Graybill JR, Hamill RJ, et al. Clinical practice guidelines for the management of cryptococcal disease: 2010 update by the infectious diseases society of america. Clin Infect Dis [Internet]. 2010 Feb 1 [cited 2013 Feb 27];50(3):291-322. Available from: http://www.ncbi. nlm.nih.gov/pubmed/20047480.

182. Graybill JR, Sobel J, Saag M, van Der Horst C, Powderly W, Cloud G, et al. Diagnosis and management of increased intracranial pressure in patients with AIDS and cryptococcal meningitis. The NIAID Mycoses Study Group and AIDS Cooperative Treatment Groups. Clin Infect Dis [Internet]. 2000 Jan [cited 2015 Jan 7];30(1):47-54. Available from: http://www.ncbi.nlm. nih.gov/pubmed/10619732.

183. Shoham S, Cover C, Donegan N, Fulnecky E, Kumar P. Cryptococcus neoformans meningitis at 2 hospitals in Washington, D.C.: adherence of health care providers to published practice guidelines for the management of cryptococcal disease. Clin Infect Dis [Internet]. 2005 Feb 1;40(3):477-9. Available from: http://www.ncbi.nlm.nih.gov/pubmed/15668874.

184. Sun H-Y, Hung C-C, Chang S-C. Management of cryptococcal meningitis with extremely high intracranial pressure in HIVinfected patients. Clin Infect Dis [Internet]. 2004 Jun 15 [cited 2015 Jan 7];38(12):1790-2. Available from: http://www.ncbi. nlm.nih.gov/pubmed/15227631.

185. Pappas PG. Managing cryptococcal meningitis is about handling the pressure. Clin Infect Dis [Internet]. 2005 Feb 1 [cited 2015 Jan 7];40(3):480-2. Available from: http://www.ncbi.nlm.nih.gov/ pubmed/15668875.

186. Kabanda T, Siedner MJ, Klausner JD, Muzoora C, Boulware DR. Point-of-care diagnosis and prognostication of cryptococcal meningitis with the cryptococcal antigen lateral flow assay on cerebrospinal fluid. Clin Infect Dis [Internet]. 2014 Jan [cited 2015 Jan 7];58(1):113-6. Available from: http://www.ncbi.nlm.nih.gov/ pubmed/24065327.

187. French N, Gray K, Watera C, Nakiyingi J, Lugada E, Moore M, et al. Cryptococcal infection in a cohort of HIV-1-infected Ugandan adults. AIDS [Internet]. 2002 May 3 [cited 2015 Jan 
7];16(7):1031-8. Available from: http://www.ncbi.nlm.nih.gov/ pubmed/11953469.

188. Liechty CA, Solberg P, Were W, Ekwaru JP, Ransom RL, Weidle PJ, et al. Asymptomatic serum cryptococcal antigenemia and early mortality during antiretroviral therapy in rural Uganda. Trop Med Int Health [Internet]. 2007 Aug [cited 2013 Feb 6];12(8):929-35. Available from: http://www.ncbi.nlm.nih.gov/pubmed/17697087.

189. Jarvis JN, Lawn SD, Vogt M, Bangani N, Wood R, Harrison TS. Screening for cryptococcal antigenemia in patients accessing an antiretroviral treatment program in South Africa. Clin Infect Dis [Internet]. 2009 Apr 1 [cited 2013 Mar 17];48(7):856-62. Available from: http://www.pubmedcentral.nih.gov/articlerender. fcgi? artid $=2875173 \&$ tool $=$ pmcentrez\&rendertype $=$ abstract.

190. Meya DB, Manabe YC, Castelnuovo B, Cook B a, Elbireer AM, Kambugu A, et al. Cost-effectiveness of serum cryptococcal antigen screening to prevent deaths among HIV-infected persons with a CD4+ cell count $<$ or $=100$ cells/microL who start HIV therapy in resource-limited settings. Clin Infect Dis [Internet]. 2010 Aug 15 [cited 2013 Mar 17];51(4):448-55. Available from: http://www. pubmedcentral.nih.gov/articlerender.fcgi?artid $=2946373 \&$ tool $=$ pmcentrez\&rendertype $=$ abstract.

191. Smith RM, Nguyen TA, Ha HTT, Thang PH, Thuy C, Xuan Lien $\mathrm{T}$, et al. Prevalence of cryptococcal antigenemia and costeffectiveness of a cryptococcal antigen screening program Vietnam. PLoS One [Internet]. 2013 Jan [cited 2013 May 22];8(4):e62213. Available from: http://www.pubmedcentral.nih. gov/articlerender.fcgi ?artid=3633872\&tool= pmcentrez\&rendertype $=$ abstract.

192. Micol R, Tajahmady A, Lortholary O, Balkan S, Quillet C, Dousset J-P, et al. Cost-effectiveness of primary prophylaxis of AIDS associated cryptococcosis in Cambodia. PLoS One [Internet]. 2010 Jan [cited 2013 May 22];5(11):e13856. Available from: http://www.pubmedcentral.nih.gov/ articlerender.fcgi? artid=2976692\&tool= pmcentrez\&rendertype $=$ abstract.

193. Micol R, Lortholary O, Sar B, Laureillard D, Ngeth C, Dousset J$\mathrm{P}$, et al. Prevalence, determinants of positivity, and clinical utility of cryptococcal antigenemia in Cambodian HIV-infected patients. J Acquir Immune Defic Syndr [Internet]. 2007 Aug 15;45(5):5559. Available from: http://www.ncbi.nlm.nih.gov/pubmed/ 17577124.
194. Jarvis JN, Govender N, Chiller T, Park BJ, Longley N, Meintjes G, et al. Cryptococcal antigen screening and preemptive therapy in patients initiating antiretroviral therapy in resource-limited settings: a proposed algorithm for clinical implementation. J Int Assoc Physicians AIDS Care (Chic) [Internet]. 2012 [cited 2013 May 22];11(6):374-9. Available from: http://www.ncbi.nlm.nih. gov/pubmed/23015379. Influential paper which has lead to major shift in systematic approach to cryptococcal meningitis in South Africa.

195. Jarvis JN, Harrison TS, Govender N, Lawn SD, Longley N, Bicanic $\mathrm{T}$, et al. Routine cryptococcal antigen screening for HIV-infected patients with low CD4+ T-lymphocyte countstime to implement in South Africa? S Afr Med J [Internet]. 2011 Apr [cited 2015 Jan 7];101(4):232-4. Available from: http://www. ncbi.nlm.nih.gov/pubmed/21786721.

196. Meyer A-CL, Kendi CK, Penner JA, Odhiambo N, Otieno B, Omondi E, et al. The impact of routine cryptococcal antigen screening on survival among HIV-infected individuals with advanced immunosuppression in Kenya. Trop Med Int Health [Internet]. 2013 Apr [cited 2015 Jan 7];18(4):495-503. Available from: http://www.pubmedcentral.nih.gov/articlerender.fcgi?artid= 3809891\&tool=pmcentrez\&rendertype=abstract. Important investigation showing no improvement in cryptococcal meningitis outcomes after implementation of a screen and treat programme which adds nuance to previously published health economic models, and reinforces the need for trials of public health measure in real-world settings.

197. Wajanga BM, Kalluvya S, Downs JA, Johnson WD, Fitzgerald DW, Peck RN. Universal screening of Tanzanian HIV-infected adult inpatients with the serum cryptococcal antigen to improve diagnosis and reduce mortality: an operational study. J Int AIDS Soc [Internet]. BioMed Central Ltd; 2011 Jan [cited 2013 Apr 29];14(1):48. Available from: http://www.pubmedcentral.nih. gov/articlerender.fcgi? artid=3197468\&tool= pmcentrez\&rendertype $=$ abstract.

198. Glickman SW, McHutchison JG, Peterson ED, Cairns CB, Harrington RA, Califf RM, et al. Ethical and scientific implications of the globalization of clinical research. N Engl J Med [Internet]. 2009 Feb 19 [cited 2014 Nov 6];360(8):816-23. Available from: http://www.nejm.org/doi/full/10.1056/ NEJMsb0803929. 